\title{
KACAPI INDUNG TEMBANG SUNDA CIANJURAN: KAJIAN ORGANOLOGI MENGGUNAKAN METODE ORGANOGRAFI DAN ORGANOGRAM DARI MANTLE HOOD
}

\author{
SKRIPSI PENGKAJIAN SENI \\ Untuk memenuhi salah satu syarat ujian akhir \\ Program Sarjana Seni \\ Program Studi Karawitan
}

OLEH

ANI ANDRIANI

15123049

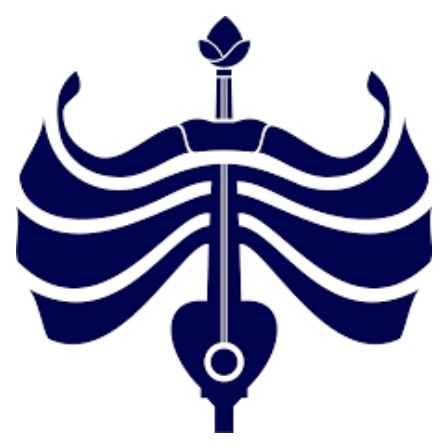

PROGRAM STUDI KARAWITAN

FAKULTAS SENI PERTUNJUKAN

INSTITUT SENI BUDAYA INDONESIA BANDUNG

TAHUN 2019 


\section{HALAMAN PERSETUJUAN \\ SKRIPSI PENGKAJIAN SENI}

Kacapi Indung Tembang Sunda Cianjuran:

Kajian Organologi Menggunakan Metode Organografi dan Organogram dari Mantle Hood

Diajukan oleh

Ani Andriani

15123049

Disetujui oleh pembimbing untuk mengikuti Ujian Akhir Pada Program Studi Seni Karawitan

Fakultas Seni Pertunjukan ISBI Bandung

Bandung, 24/06/2019

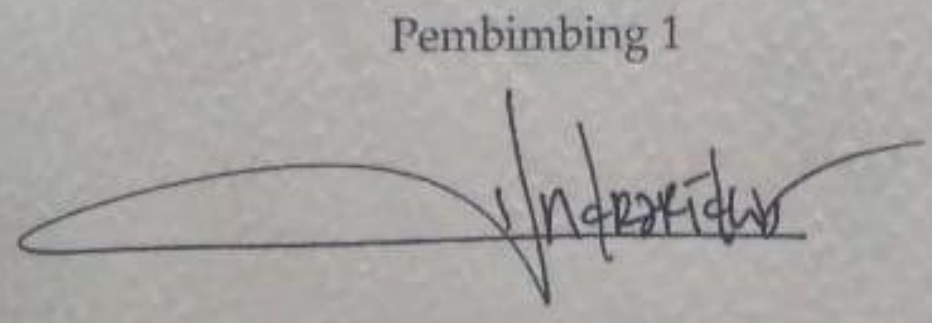

Indra Ridwan, S.Sos., M.Sn., Ph.D. NIP. 196806091998031002
Pembimbing 2

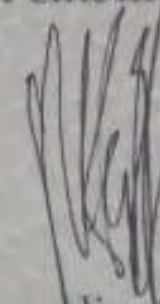

Komarudin, S.Kar., M.M.

NIP. 196105161986101001

\section{Mengetahui,}

Ketua Program Stucd Karawitan

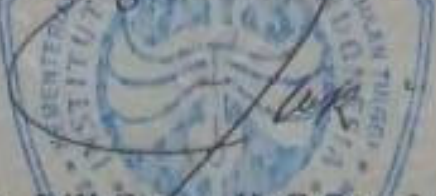

Dr. Lili suparti, S.Sn, M.Sn. 


\section{LEMBARAN PENGESAHAN SKRIPSI PENGKAJIAN SENI}

Kacapi Indung Tembang Sunda Cianjuran:

Kajian Organologi Menggunakan Metode Organografi dan Organogram dari Mantle Hood

\section{Oleh \\ ANI ANDRIANI \\ 15123049}

Telah dipertahankan di depan dewan penguji melalui Sidang Tugas Akhir Pada Tanggal 24/ Juni/ 2019

\section{Susunan Dewan Penguji}

Ketua Dewan Penguji $\quad$ : Dr. Heri Herdini, M.Hum.

Penguji Ahli

; Saryoto, S.Kar., M.Hum.

Anggota Penguji

: Dr. Endah Irawan., M.Hum.

Anggota Penguji

Penguji Advokasi

: Drs. Dadang Suganda, M.M.

: Indra Ridwan, S.Sos., M.Sn., Ph.D.

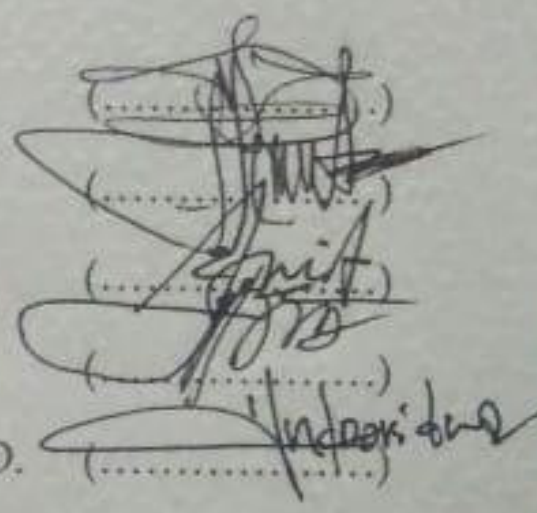

Pertanggung jawaban tertulis karya tulis ini telah disahkan sebagai salah satu persyaratan untuk memperoleh gelar Sarjana Seni Fakultas Seni pertunjukan, Institut Seni Budaya Indonesia (ISBI) Bandung

Mengetahui,

Bandung, 24 Juni 2019

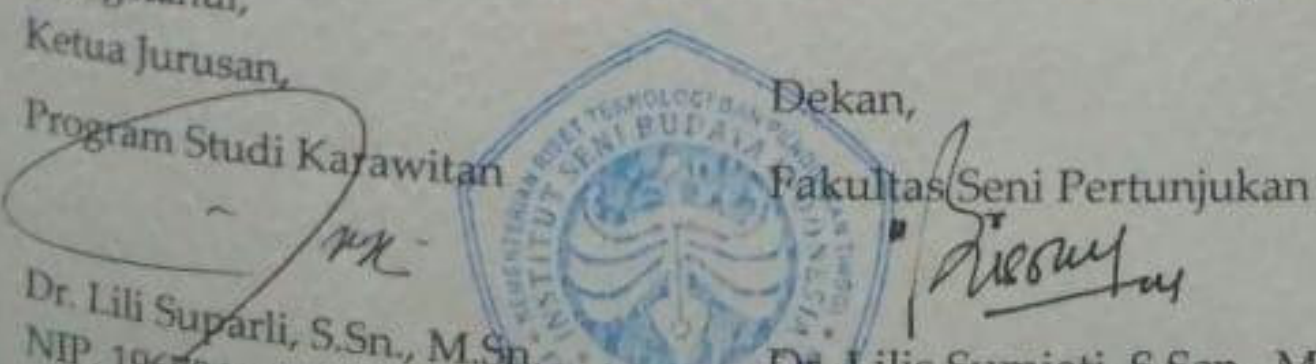

NIP. 196 parli, S.Sn., M.Sn. 2 Dr. Lilis Sumiati, S.Sen., M.Sn. NHP. 196711141993022001 


\section{PERNYATAAN}

Saya menyatakan bahwa SKRIPSI PENGKAJIAN SENI dengan judul: “Kacapi Indung Tembang Sunda Cianjuran: Kajian Organologi Menggunakan Metode Organografi dan Organogram dari Mantle

Hood" beserta seluruh isinya adalah benar-benar karya saya sendiri. Saya tidak melakukan penjiplakan atau pengutipan atau tindakan plagiat melalui cara-cara yang tidak sesuai dengan etika akademik. Saya bertanggungjawab dengan keaslian karya ini dan siap menanggung resiko atau sanksi apabila dikemudian hari ditemukan hal-hal yang tidak sesuai dengan pernyataan ini.

Bandung, 10/ Juli/ 2019

Yang membuat pernyataan

Tanda tangan

Ani Andriani

15123049 


\begin{abstract}
ABSTRAK
Penelitian ini dilatarbelakangi oleh kurangnya penelitian perihal organologi instrumen khususnya instrumen Sunda, salah satunya yakni kacapi. Terdapat beberapa jenis kacapi di antaranya, kacapi pantun, kacapi kawih wanda anyar, dan kacapi tembang Sunda cianjuran. Instrumen yang menjadi objek penelitian yakni kacapi indung tembang Sunda cianjuran. Dengan rumusan masalah bagaimana organografi dan organogram kacapi indung tembang Sunda cianjuran berdasarkan metode Mantle Hood. Dalam mengklasifikasikan instrumen terdapat sebuah metode untuk membedahnya yaitu metode organografi dan organogram dari Mantle Hood. Metode tersebut dilandaskan dengan teori Hood itu sendiri yakni perspektif berfikir berdasarkan garis G - S (General to Spesifik). Metode yang dibuat oleh Hood, wujud jadinya berupa gabungan dari simbol-simbol, berbeda dengan sistem pengklasifikasian yang dibuat oleh Sachs dan Hornbostel yang wujud jadinya berupa deretan angka yang disebut dengan Sistem Dewey Decimal. Hasil akhirnya, kacapi indung tembang Sunda cianjuran diinterpretasikan melalui gabungan simbol-simbol yang dijelaskan secara visual serta dapat menyampaikan banyak informasi secara singkat padat dan jelas.
\end{abstract}

Kata kunci: organografi, organogram, kacapi indung, tembang Sunda cianjuran. 


\section{KATA PENGANTAR}

Puji Syukur kehadirat Allah Swt atas segala nikmat serta semangat dan kekuatan yang diberikan sehingga skripsi yang berjudul "Kacapi Indung Tembang Sunda Cianjuran: Kajian Organologi Menggunakan Metode Organografi dan Organogram dari Mantle Hood" ini dapat selesai tepat pada waktunya. Shalawat serta salam untuk tuntunan dan suri tauladan Rasulullah Saw beserta keluarga dan sahabat beliau yang menjunjung tinggi nilai-nilai Islam yang hingga saat ini bisa dinikmati oleh seluruh umat di penjuru dunia.

Skripsi ini disusun untuk memenuhi salah satu persyaratan mencapai derajat Sarjana (S1) Program Studi Karawitan di Institut Seni Budaya Indonesia (ISBI) Bandung.

Penulis menyadari sepenuhnya bahwa begitu banyak pihak yang ikut terlibat dan membantu dalam penyelesaian skripsi ini. Oleh karena itu, dalam kesempatan ini dengan segala kerendahan hati penulis mengucapkan terima kasih yang sebesar-besarnya kepada: 
1. Dr. Hj. Een Herdiani, M.Hum., selaku Rektor ISBI Bandung beserta jajarannya yang telah berusaha memberikan fasilitas dan pelayanan terbaik kepada mahasiswa semasa perkuliahan;

2. Dr. Lilis Sumiati, S.Sen., M.Hum., selaku Dekan Fakultas Seni Pertunjukan;

3. Ketua Program Studi Karawitan Dr. Lili Suparli, M.Sn., yang sekaligus sebagai dosen wali bagi penulis. Beliau memberikan banyak motivasi dan arahan sehingga tulisan ini bisa selesai;

4. Indra Ridwan, S.Sos., M.Sn., M.A., Ph.D., sebagai Pembimbing I yang selalu rela meluangkan waktunya untuk berdiskusi lewat sosial media atau bertatapan langsung;

5. Dinda Satya Upaja Budi, M.Hum., yang selalu sabar membimbing dan menuntun penulis dalam menyelesaikan setiap permasalahan penelitian ini dan memberikan motivasi agar penelitian cepat selesai;

6. Komarudin, S.Sn., M.Sn., sebagai Pembimbing II yang begitu sabar serta rela meluangkan waktu untuk berdiskusi dan membantu dalam teknik penulisan; 
7. Para dosen dan staf pengajar yang telah memberikan banyak ilmu kepada anak didiknya dengan cara yang terbaik dalam perkuliahan;

8. Narasumber yang telah meluangkan waktunya untuk wawancara dengan pertanyaan-pertanyaan yang dilontarkan penulis dan dijawab dengan sabar demi kelengkapan data objektif;

9. Secara khusus penulis mengucapkan terimakasih kepada Bunga Dessri Gauliyah, M.Sn. yang sudah dianggap sebagai kakak sendiri. Bunga yang senantiasa memberikan arahan, pencerahan, motivasi, kepada penulis hingga saat ini dengan penuh keikhlasan dan ketulusan;

10. Yusdiana serta keluarga yang rela meluangkan waktunya untuk berdiskusi dan direpotkan dikala penulis merasa kebingungan dan kelelahan;

11. Penulis juga mengucapkan terimakasih, terlebih khusus kepada PASKIBRA yang terdiri dari; Aida Nur Fitriani Lustian, Andin Sri Anisa, Sharfina Ghasani (sapi), Irna (Inot Geboy), begitu juga kepada teman-teman Taekwondo Kita Saudara, Pelatih (Sabeum 
Nim Irfan Fahrul), Taekwondo SMAN 1 Soreang, yang telah memberikan motivasi dan menjadi penyemangat bagi penulis;

12. Juga kepada Sayyidah Rabi'ah, S.Pd yang telah sabar menemani dan membantu penulis dalam menyelesaikan skripsi ini;

13. Keluarga besar HIMAKA dan angkatan Mungdinglaya 2015 yang menjadi teman seperjuangan;

14. Terakhir, rasa termakasih yang sebesar-besarnya kepada kedua orangtua yang begitu banyak pengorbanan baik dari materi, batin dan mental, yang belum pasti penulis balas. Perjuangan kedua orang tua yang luar biasa ini menjadi pacuan semangat agar penulis termotivasi dan menyelesaikan studi ini; begitu pun kepada adik, sepupu, dan saudara, penulis ucapkan terimakasih untuk pemberian semangat dan motivasinya.

Tulisan ini masih sangat jauh dari kata sempurna, karena kesempurnaan hanya milik Allah SWT. Hal ini semata-mata karena terbatasnya kemampuan dan terbatasnya pengetahuan yang penulis miliki. Oleh karena itu, penulis mengharapkan saran dan kritikan yang positif dan membangun demi kesempurnaan tulisan-tulisan yang akan 
datang. Akhirnya, harapan penulis adalah semoga tulisan ini bisa bermanfaat dan dapat memberikan kontribusi kepada pembaca, dapat menjadi sumber referensi dan memberikan pengetahuan kepada para peneliti untuk di masa yang akan datang. 


\section{DAFTAR ISI}

HALAMAN JUDUL

HALAMAN PERSETUJUAN

LEMBARAN PENGESAHAN

PERNYATAAN

ABSTRAK

KATA PENGANTAR ............................................................................ vi

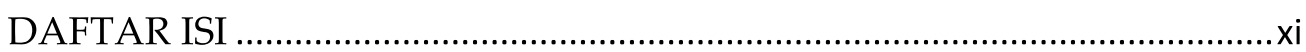

DAFTAR GAMBAR ....................................................................................

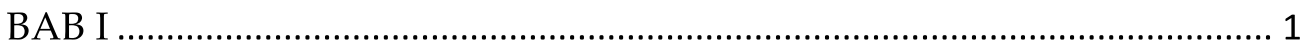

1.1 Latar Belakang Masalah .................................................................. 1

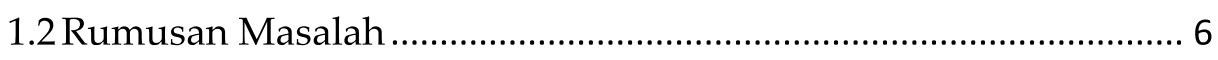

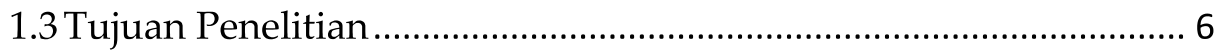

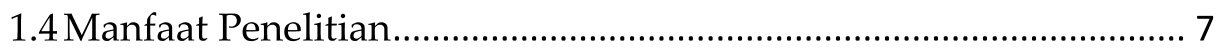

1.Aspek Teoretis ............................................................................. 7

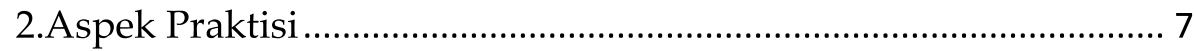

1.5 Tinjauan Pustaka ....................................................................... 7

1.6 Landasan Teori................................................................................ 10

1.7 Metode Penelitian ...................................................................... 14

1.8Sistematika Penulisan ................................................................. 18

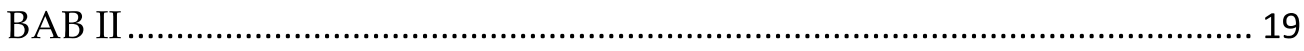

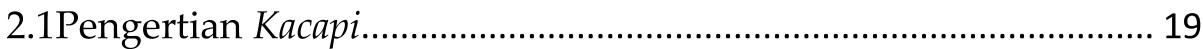

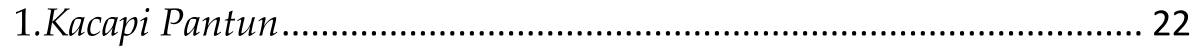

2.Kacapi Kawih Wanda Anyar ........................................................... 29

3.Kacapi Indung Tembang Sunda Cianjuran ....................................... 40 


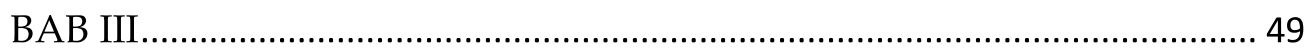

3.1 Sekilas tentang Organologi .......................................................... 49

3.2 Klasifikasi Instrumen Kacapi Indung ......................................... 50

1.Dewey Decimal System Sachs - Hornbostel.................................... 55

2.Kodifikasi Dewey Decimal System pada Instrumen Kacapi Indung 58

3.Organografi dan Organogram Kacapi Indung.............................. 60

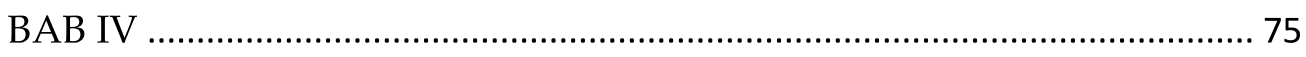

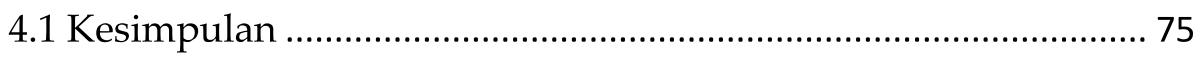

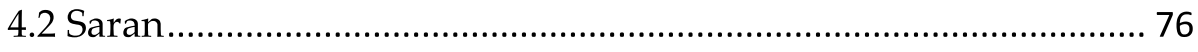

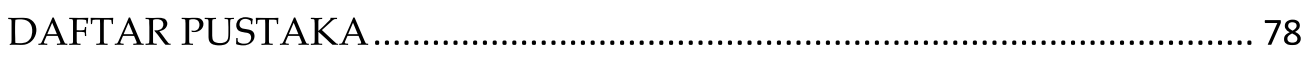

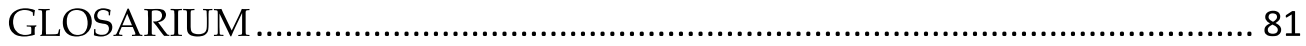

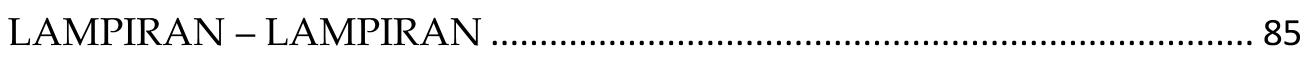

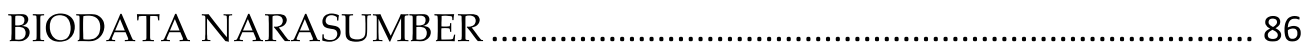

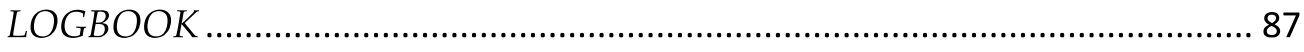

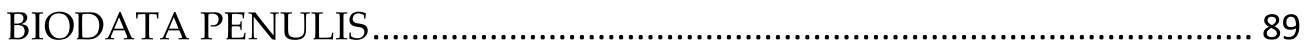




\section{DAFTAR GAMBAR}

Tabel 1. Interval tngga nada dari setiap laras..........................21

Gambar 1. Konsep berfikir teori Mantle Hood............................................ 12

Gambar 2. Implementasi konsep berpikir Mantle Hood.

(Sumber: Penulis, 2019).......................................................... 13

Gambar 3. Kacapi sebelum tahun 1894 ...................................................... 28

Gambar 4. Pemain kacapi pantun dari Cikadu, Kanékès, tahun 1976. Kacapi yang dimainkan memiliki 12 dawai.

Gambar 5. Pasanggiri Juru Kawih Satatar Sunda, yang dilaksanakan pada tanggal 16 Desember tahun 2018, di SMK 10 Bandung. 30

Gambar 6. Penampilan kesenian celempungan yang menggunakan kacapi kawih atau siter (sumber: Youtube, Khidhir Kuskus, 2014).

Gambar 7. Penampilan kesenian jenaka Sunda dengan kacapi yang berjumlah dawai 20 utas (sumber: Blog baixar, 2017). 33

Gambar 8. Sketsa ukuran kacapi kawih 34

Gambar 9. Kacapi kawih; berdasarkan jumlah dawai dan jenis dawai. 35

Gambar 10. Inang kacapi tembang seperti piramid...................................... 36

Gambar 11. Kacapi kawih tampak atas. .......................................................... 36

Gambar 12. Kacapi kawih tampak bawah; bagian resonator. 37

Gambar 13. Koleksi kacapi buatan Desmon (sumber: dok. Pribadi, 2019). 38

Gambar 14. Kreativitas pengrajin dengan ditambahkannya dekorasi dan bentuk yang unik (sumber: dok. Musiktradisional Sunda. Deskgram.net, 2018). 39 
Gambar 15. Kacapi dengan diberi ukiran pada bagian

atas (sumber: dok. Ahmad Saepudin, 2015).

Gambar 16. R.A.A. Kusumaningrat

(sumber: http://cianjuranku.blogspot.com

/2015/12/pahlawan-cianjuran.html?m=0, 2015).

Gambar 17. Kawat kuningan yang dominan dipakai

pada instrumen kacapi indung tembang

Sunda cianjuran. 43

Gambar 18. Merupakan baut untuk mengaitkan dawai. ........................... 44

Gambar 19. Paku yang digunakan untuk membuat kacapi......................... 45

Gambar 20. Pemain kacapi indung memakai stand saat .............................. 47

Gambar 21. Pertunjukan tembang Sunda cianjuran, dengan instrument kacapi indung yang memakai stand dengan ditutupi kain. 47

Gambar 22. Perkembangan klasifikasi instrumen musik Sachs dan Hornbostel. (Sumber: Deborah Lee.

ISKO, 2019) 52

Gambar 23. Hubungan antara versi MIMO Sachs dan

Hornbostel dan antesedennya, termasuk penambahan elektrofon. 54

Gambar 24. Klasifikasi kacapi indung berdasarkan

Dewey Decimal System. 59

Gambar 25. Taksonomi simbolik organogram Mantle Hood. 62

Gambar 26. Organografi dan organogram kacapi indung (sumber: Ani Andriani, 2019). 63

Gambar 27. Deskripsi fisik organogram kacapi indung. 64

Gambar 28. Deskripsi fisik organogram kacapi indung dilihat dari simbol posisi pemain dan teknik memainkan.

Gambar 29. Deskripsi fisik organogram kacapi indung secara teknis. 66

Gambar 30. Deskripsi fisik organogram, kacapi indung 67

Gambar 31. Deskripsi fisik organogram, kacapi indung secara non teknis. 
Gambar 32. Deskripsi fisik organogram secara non teknis........................ 71

Gambar 33. Kacapi indung tahun 1871 dari sisi samping dan

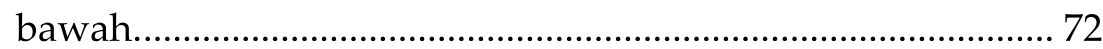

Gambar 34. Kacapi indung tahun 1921........................................................ 72 


\section{BAB I}

\section{PENDAHULUAN}

\subsection{Latar Belakang Masalah}

Tembang Sunda cianjuran adalah salah satu jenis kesenian tradisional Sunda yang berbentuk sekar gending atau memadukan dua unsur sekaligus yakni sekar yang diwujudkan oleh vokal, dan gending oleh berbagai waditra atau alat musik pengiringnya. Beberapa waditra yang biasanya mengiringi kesenian yang berasal dari Cianjur ini di antaranya kacapi indung, kacapi rincik, suling, dan atau rebab. Dalam penyajiannya, berbagai waditra tersebut berperan sesuai dengan fungsi dan perannya masing-masing.

Di antara beberapa waditra pengiring tembang Sunda cianjuran, waditra yang dapat dianggap inti dari kesenian ini adalah kacapi indung karena waditra tersebut memiliki peran yang sangat penting (vital), yakni bertugas menyajikan tabuhan pokok lagu dari awal hingga akhir. Hal tersebut berbeda dengan peran waditra lainnya, misalnya kacapi rincik yang digunakan untuk menambah kekayaan musikal suatu iringan, atau suling dan rebab yang berfungsi sebagai pembawa melodi. Dengan demikian, 
baik itu vokal maupun waditra lainnya, sangat bergantung pada kacapi indung.

Pentingnya peran kacapi indung dalam tembang Sunda cianjuran pun dapat diidentifikasi dari asal katanya, yakni indung atau ibu (Yus Wiradiredja, 2016: 153). Hal tersebut dapat dikaitkan dengan seorang ibu dalam masyarakat Sunda yang berperan menjaga dan tempat bergantung dari anak-anaknya. Selain itu, pasangan kata indung dan anak pun menunjukkan bentuk koneksi antara dewasa dan kanak-kanak ${ }^{1}$, yang dalam tembang Sunda cianjuran dapat diidentifikasi dari ukuran kacapi indung yang lebih besar dari waditra-waditra lainnya, terutama instrumen sejenis (instrumen berdawai) seperti kacapi rincik.

Secara organologis ${ }^{2}$, kacapi indung diklasifikasikan sebagai alat musik chordophone yakni alat musik yang sumber bunyinya berasal dari getaran dawai yang bergetar di antara dua titik ${ }^{3}$. Selain itu, kacapi indung pun

1 Ciri umum usia dewasa adalah postur tubuh yang besar, sedangkan usia kanak-kanak postur tubuh yang ukurannya kecil.

2 Organologi - ilmu instrumen musik - mempelajari tentang struktur musik dan sejarah, akan tetapi sama pentingnya pada aspek instrumen musik seperti teknik pertunjukan, fungsi musik, dekorasi dan berbagai pertimbangan sosial-budaya (Mantle Hood, 1971: 124).Ada pendapat lain juga yang menyatakan bahwa, Organologi mempelajari tentang struktur instrumen musik berdasarkan sumber bunyi, cara memproduksi bunyi, dan sistem pelarasan. Serta mempunyai gambaran tentang bentuk dan rupa susunan/ konstruksi suatu instrumen sehingga dapat menghasilkan bunyi seperti instrumen lainnya (Pardon Simbolon, "Mata Kuliah Akustika Organologi", (http://pardonsimbolon.blogspot.com/2012/08/akustik-organologi.html , 28/11/2018 11.08)

${ }^{3}$ Dalam hal ini, kacapi indung memiliki 18 dawai berbahan kuningan, dengan menggunakan tangga nada pentatonis (da mi na ti la). 
menyajikan keunikan dari segi bentuk dan bahan. Secara bentuk, wujud fisik kacapi indung menyerupai parahu (Indonesia: sampan/perahu). Hal tersebut kemudian membuat kacapi ini pun disebut sebagai kacapi parahu. Keunikan lain dari waditra ini adalah gelung (sanggul) yang terdapat pada kedua sisinya (kanan dan kiri), yang kemudian membuat waditra ini pun sering disebut kacapi gelung. Secara bahan, waditra ini menjadi unik karena terbuat dari kayu. Kayu yang lazim digunakan untuk membuat kacapi bermacam-macam. Menurut Hermawan, dalam Sukanda, (1996: 7) kayu yang digunakan antara lain: cempaka putih (Michelia Alba); kananga (Cananga Odoratum); manglid (Mongolia Blumei); suren (Toona Sureni); dan lame (Alstonia Scholaris).

Keberadaan kacapi indung, dengan segala keunikannya, dapat menggambarkan teknologi orang Sunda pada masa lampau, yang masih terpelihara bahkan dikembangkan hingga saat ini. Namun sangat disayangkan, hingga saat ini kajian atau penelitian yang memformulasikan permasalahan kacapi indung dari aspek fisik atau rupa masih sangat jarang. Adapun penelitian yang sudah dilakukan, misalnya hanya mengulas bentuk kacapi indung secara singkat dan sekilas, atau tidak khusus membahas organologi secara detail, menyebabkan banyak 
masyarakat, baik itu pelajar, mahasiswa, maupun guru yang tidak mengenal kacapi indung secara mendalam ${ }^{4}$.

Atas dasar hal di atas, permasalahan bentuk dan rupa instrumen kacapi indung menjadi permasalahan yang menarik untuk dikaji lebih dalam. Berbagai pertanyaan penelitian muncul ketika membahas kacapi indung, misalnya bentuknya yang unik dan representasi bangunan perahu sampan menjadi pertanyaan mengenai aktivitas masyarakat Sunda dengan aktivitas kemaritiman pada masa lampau; kemudian, bentuknya yang disandingkan dengan lisung atau tempat menumbuk padi, juga menjadi pertanyaan mengenai kaitannya dengan aktivitas berladang, bertani atau aktivitas penghormatan terhadap Dewi Padi (Nyai Sri Dangdyang Tresnawati) pada masyarakat Sunda; atau hiasan gelung (Indonesia: ikatan rambut) yang melekat sebagai elemen instrumen yang dipersonifikasikan sebagai sosok perempuan pun dapat menjadi pertanyaan yang menarik dalam penelitian. ${ }^{5}$

${ }^{4}$ Mahasiswa di kampus seni yang mempelajari kesenian tradisional Sunda, misalnya prodi Karawitan ISBI Bandung, mungkin sudah mengetahui fungsi bagian dari kacapi walaupun kurang mendetail, namun pada masyarakat Sunda pada umumnya, khususnya generasi muda, banyak yang bahkan tidak mengenal kacapi indung sama sekali.

5 Wim van Zanten, Atik Soepandi, dan Heri Herdini dalam tulisannya menyatakan bagian dari elemen kacapi dipersonifikasikan sebagai elemen tubuh wanita: inang sebagai payudara, gelung sebagai bagian rambut, dan lubang resonator (cukang beurit) sebagai alat kelamin wanita (vagina). 
Pertanyaan yang terkait dengan organologi kacapi indung pun masih beragam, seperti bentuk hiasan atau ornamen dan bagian kacapi indung yang melekat beserta fungsinya (misalnya fungsi inang, pureut, cukang beurit, dan gelung); ukuran besar yang merepresentasikan sosok indung; jenis kayu yang dipandang baik untuk bahan kacapi indung; dan sejumlah pertanyaan lain yang berkontribusi bagi penemuan karawitan sebagai disiplin ilmu (karawitanologi).

Pertanyaan-pertanyaan mengenai organologi kacapi indung seperti di atas, salah satunya dapat diteliti dengan menggunakan suatu metode yang digagas oleh Mantle Hood yang mengetengahkan sistem klasifikasi alat musik berbentuk kodifikasi ${ }^{6}$ organografi dan organogram ${ }^{7}$. Sistem tersebut sangat menarik karena dapat mempermudah para kolektor atau museum di dunia, terutama menyusun katalog untuk klasifikasi instrumen musik yang menjadi barang koleksi museum. Atas dasar hal tersebut, langkah kerja Mantle Hood dalam menyusun organografi dan organogram dapat dijadikan sebuah alternatif bagi para organolog,

\footnotetext{
${ }^{6}$ Kodifikasi adalah pemberian nomor atau lambang pada perkiraan pos, jurnal, faktur, atau dokumen lain yang berfungsi sebagai alat untuk membedakan pos yang satu dengan lainnya yang termasuk [dalam] satu golongan (https://kbbi.web.id/kodifikasi, diakses pada tanggal 22 Februari 2019, pukul 23:44 WIB)

7 Bahasan mengenai organogram dan organografi secara lengkap dibahas pada subbab landasan teori.
} 
khususnya pengkaji karawitan Sunda, termasuk penulis yang mengkaji kacapi indung dalam tembang Sunda cianjuran.

\subsection{Rumusan Masalah}

Dari berbagai permasalahan yang ada, sebagaimana yang telah dipaparkan dalam latar belakang, penelitian ini difokuskan pada wilayah organografi dan organogram. Adapun rumusan masalah penelitian ini adalah "Bagaimana organografi dan organogram kacapi indung tembang Sunda cianjuran berdasarkan metode Mantle Hood?".

\subsection{Tujuan Penelitian}

Tulisan ini bertujuan untuk mengetahui dan menjelaskan organografi dan organogram kacapi indung dalam tembang Sunda cianjuran berdasarkan metode Mantle Hood, juga perlu disebarluaskan kepada para organolog khususnya seniman Sunda, untuk mempermudah dalam mendeskripsikan sekaligus menyederhanakan sebuah instrumen dari bentuk aslinya. Selain itu, studi yang dihasilkan dapat memberi wawasan tambahan kepada para pelaku seni, peneliti seni, pengrajin waditra, dan masyarakat pada umumnya yang ingin mengetahui permasalahan mengenai organologi kacapi indung dari kajian organografi dan organogram. 


\subsection{Manfaat Penelitian}

Penelitian ini diharapkan dapat memberikan manfaat dalam tataran aspek teoretis dan praktis, dengan eksplanasi sebagai berikut :

1. Aspek Teoretis

Secara teoretis hasil penelitian ini bermanfat untuk perkembangan ilmu pengetahuan, serta memberikan sumbangan keilmuan untuk karawitan, khususnya yang berkaitan dengan bidang organologi pada kacapi indung dalam tembang Sunda cianjuran.

\section{Aspek Praktisi}

Secara praktis diharapkan dapat bermanfaat bagi masyarakat luas, khususnya bagi pelaku seni dan pengrajin hingga dapat dijadikan sebuah wawasan yang dipakai sebagai pengetahuan dalam organologi instrumen kacapi indung dalam tembang Sunda cianjuran. Selain itu, dapat digunakan oleh para kolektor atau museum untuk mengelompokkan instrumen.

\subsection{Tinjauan Pustaka}

Sumber yang digunakan dalam penelitian ini terdiri atas sumber tulisan yang relevan dan digunakan sebagai rujukan oleh penulis. Sumber tulisan diperoleh dari hasil penelitian maupun buku yang berhubungan dengan penelitian. Adapun sumber tertulis yang dimaksud adalah: 
1. Tulisan yang khusus mengetengahkan organologi dan akustika ditulis oleh Sri Hendarto berjudul Organologi dan Akustika IEII (2011), diterbitkan di Bandung oleh CV. Lubuk Agung. Buku ini menjelaskan tentang persoalan pengklasifikasian alat musik yang dibuat dengan cara sistem DDS (Dewey Decimal System) yang wujud jadinya berupa deretan angka. Deretan angka yang dibuat oleh Sachs - Hornbostel ${ }^{8}$ ini menunjukkan klasifikasi alat musik, bahan, cara memainkan serta bentuk instrumen musik secara detail. Hanya saja dalam bentuk atau wujud berupa gambar (organogram) dari instrumen tidak disertakan oleh penulisnya. Buku ini membahas pula persoalan akustika dan jenis-jenis alat musik yang ada di Asia Tenggara, namun alat musik khas Tatar Sunda khususnya kacapi, hanya disinggung sedikit, sehingga, hal tersebut akan menjadi pembeda dengan penelitian ini, yang akan membahas organografi dan organogram kacapi indung tembang Sunda cianjuran.

2. Sundanese Music in The Cianjuran Style (1989), ditulis oleh Wim van Zanten. Dalam buku itu dijelaskan tentang instrumen tembang

${ }^{8}$ Sach dan Hornbostel adalah seorang musikolog yang merancang sebuah sistem pengklasifikasian alat musik dari berbagai kebudayaan. Sistem tersebut dipublikasikan pertama kali di Galpin Society Journal pada tahun 1961. 
Sunda pada bab V. Zanten menulis tentang cara memainkan kacapi indung dan rincik, laras (tangga nada) yang diterapkan pada instrumen, dan bentuk serta proses pembuatan kacapi indung. Akan tetapi, titik berat kajian Zanten lebih mengarah kepada aspek antropologis, sedangkan kajian yang akan dilakukan penulis lebih berorientasi pada ranah organologi instrumen, khususnya kacapi indung. Jelas penelitian Zanten akan berbeda dengan penelitian yang akan dilakukan oleh penulis.

3. Buku The Ethnomusicologist (1982), karya Mantle Hood yang monumental, diterbitkan di Amerika oleh The Kent State University Press. Sebagai penjelasan literasi musik, cara transkripsi, dan metode penelitian yang dijadikan pijakan awal para Etnomusikolog dalam mengkaji musik bangsa-bangsa (etnis) pada awal kemunculan disiplin ilmu Etnomusikologi di Amerika9 . Pada bab III diketengahkan permasalahan organologi sebagai ranah yang menjadi fokus kajian penting dalam suatu penelitian. Hood menawarkan konsep yang dijadikan metode dalam mengkaji instrumen musik, yakni kodifikasi organografi dan organogram. Kaitannya dengan rencana penelitian penulis maka

${ }^{9}$ Mantle Hood adalah bapak Etnomusikologi Amerika. Ia adalah orang pertama yang mendirikan program studi Etnomusikologi di Amerika. 
metode Mantle Hood tentang organografi dan organogram menjadi "pisau bedah" yang membantu penulis untuk mengkaji organologi kacapi indung.

4. Disertasi Dinda Satya Upaja Budi yang berjudul Angklung Dogdog Lojor Pada Masyarakat Kasepuhan Ciptagelar Kasatuan Adat Banten Kidul (2015), diterbitkan UGM Yogyakarta. Tulisan ini membahas mengenai angklung dogdog lojor dari sisi organologi, dan memaparkan tentang masyarakat Kasepuhan Ciptagelar yang dibahas secara mendalam. Pada bab III dibahas perihal organografi dan organogram, akan tetapi instrumen yang diteliti yaitu angklung dogdog lojor. Kaitannya dengan rencana penelitian penulis yaitu kajian yang sama, akan tetapi instrumen yang dikaji berbeda, yaitu instrumen kacapi indung tembang Sunda cianjuran. Sehingga, penelitian Dinda akan berbeda dengan penelitian yang akan dilakukan penulis.

\subsection{Landasan Teori}

Penelitian ini mengungkap sebuah alat musik kacapi indung, ditinjau dari aspek organografi dan organogram. Kajian terhadap alat musik ini dapat memberi informasi penting untuk peneliti. Hal tersebut 
sebagaimana yang diungkapkan Hood bahwa alat musik merupakan sumber informasi yang unik (Hood, 1971: 123). Keberadaan alat musik tersebut terkait erat dengan organologi yang merupakan bahasan utama dalam penelitian ini.

Istilah "organologi" tidak ditemukan dalam Kamus Musik Harvard, namun istilah tersebut telah diterima secara luas di kalangan musikolog (Hood, 1971: 123). Berkaitan dengan hal tersebut, Hood menyarankan untuk memikirkan kembali istilah yang lebih akurat untuk konsentrasi deskriptif istilah "organologi" menjadi "organografi" (didefinisikan dalam edisi kedua dari Kamus Webster. “1.A. Deskripsi instrumen. Obs.”)(1971: 123).

Organografi disebut sistem utama klasifikasi, karena di budaya Cina, India dan Eropa Barat telah dikembangkan taksonomi alat musik berdasar material yang digunakan sebagai bahan pembuatan alat tersebut. Mantle Hood membuat sistem pengklasifikasian yang pada dasarnya hampir serupa dengan sistem Sachs dan Hornbostel, hanya saja Hood menggunakan sebuah simbol dengan wujud gambar atau kerap kali disebut dengan istilah organogram. Organogram adalah notasi simbol instrumen musik yang dibuat oleh Hood untuk penyederhanaan dari bentuk instrumen yang sesungguhnya. Semacam ideogram yang dapat 
mengemas banyak informasi unik dalam bentuk visual, yang tidak terlalu sulit untuk dipahami. Ia terinspirasi dari sistem notasi laban (simbol untuk tari).

Salah satu orientasi yang mungkin untuk memperjelas maksud dan tujuan dalam kajian ini, Hood membuat perspektif berpikir berdasarkan garis $G-S$, yakni struktur kajian peneliti yang memulai kajian dari General (umum) sampai Specific (spesifik). Garis ini membantu struktur berpikir yang runut, untuk melacak sebuah informasi yang masih cukup umum yang dikupas menjadi datum-datum informasi yang lebih spesifik. Kajian G - S akan lebih bernilai dengan melakukan studi kasus. Studi kasus yang diambil sesuai dengan kajian yaitu pada instrumen.Berikut ini merupakan kerangka berpikir dari teori G - S yang ditawarkan Mantle Hood:

The norms of musical style

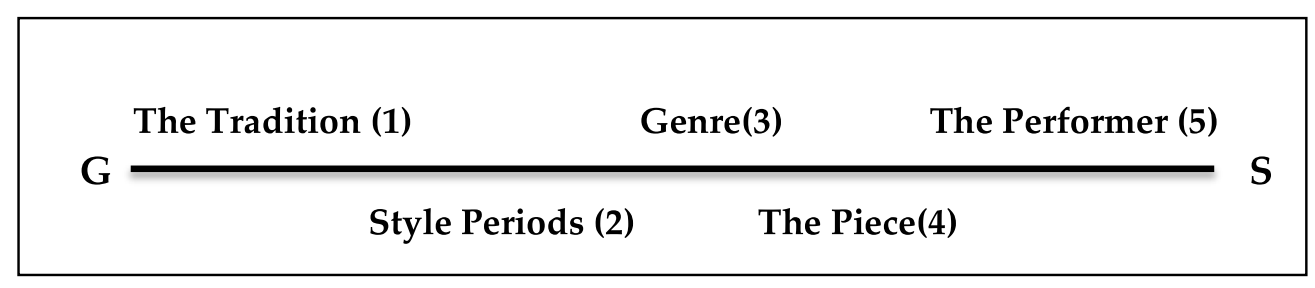

Gambar 1. Konsep berfikir teori Mantle Hood. Sumber: Mantle Hood (1971: 303). 
Korelasi teori Hood dengan kajian penulis berdasarkan garis G - S di atas diimplementasikan penulis melalui bagan berikut:

The design of organology kacapi ndung

\begin{tabular}{|c|c|c|c|}
\hline \multirow{2}{*}{$G$} & The Tradition(1) & Classification(3) & Organogram(5) \\
\hline & Instrument(2) & Org & o \\
\hline
\end{tabular}

Gambar 2. Implementasi konsep berpikir Mantle Hood. (Sumber: Penulis, 2019).

Bagan di atas merupakan poin-poin yang dibuat untuk membedah informasi yang sangat umum dari keberadaan kacapi indung, dimulai fenomena tembang Sunda cianjuran sebagai bahasan yang bersifat umum hingga bahasan yang lebih spesifik, yakni tentang organografi dan organogram. Adapun objek yang menjadi fokus kajian adalah instrumen kacapi indung. Singkat kata, rencana teori yang diaplikasikan dalam penelitian ini, akan menggunakan teori Mantle Hood sebagai pisau bedah yang komprehensif dalam membantu analisisis data. 


\subsection{Metode Penelitian}

Penulis telah melakukan kajian dengan metode penelitian deskriptif yang menjelaskan kacapi indung tembang Sunda cianjuran melalui pendekatan organologi yang menggunakan metode Mantle Hood. Adapun langkah-langkah yang dilakukan penulis untuk melakukan penelitian adalah sebagai berikut :

\section{Teknik Pengumpulan Data}

Pengumpulan data meliputi kegiatan studi pustaka, wawancara, observasi, dan dokumentasi. Penjabaran kegiatan tersebut adalah sebagai berikut:

\section{a) Studi Pustaka}

Studi pustaka dilakukan penulis untuk mendapatkan data atau bahan literatur yang mendukung aktivitas penelitian di lapangan mengenai pengetahuan organologi, klasfikasi, organogram, organografi dan yang berkaitan juga dengan instrumen kacapi indung. Studi pustaka ini menjadikan hasil kajian menjadi bersifat orisinal. Studi pustaka ini dilakukan di beberapa perpustakaan, di antaranya Institut Seni Budaya Indonesia (ISBI) Bandung, Institut Seni Indonesia (ISI) Surakarta, dan perpustakaan daerah Bandung. Selain itu, penelusuran pustaka pun dapat 
menghasilkan input kerangka berpikir para ahli dalam memecahkan masalah penelitian. Studi pustaka yang dilakukan penulis meliputi studi terhadap sumber primer dan sekunder, seperti buku, skripsi, disertasi, artikel, dan tulisan lainnya.

b) Wawancara

Wawancara ditujukan kepada narasumber yang memiliki latar belakang sebagai praktisi dan pengrajin. Salah satu pengrajin yang dijadikan sebagai narasumber adalah Desmon yang didasari oleh kredibilitasnya sebagai seorang produsen kacapi indung dengan kualitas yang unggul ${ }^{10}$. Dalam hal ini, Desmon diwawancara mengenai proses pembuatan beserta fungsi dari bagian-bagian kacapi indung. Namun, ada beberapa informasi yang peneliti dapat dari Desmon selain dari bagianbagian kacapi indung, yaitu kacapi kawih. Dalam wawancara peneliti tidak bertanya begitu mendalam perihal kacapi kawih hanya sebatas gambaran umum untuk membedakan bagian-bagian dari kacapi indung dan kacapi kawih.

${ }^{10}$ Hasil karya Desmon telah diakui oleh para pelaku seni (seniman akademis dan seniman alam) serta instansi (dinas kebudayaan, sekolah, sanggar). 
c) Observasi

Dalam penelitian ini, observasi merupakan hal yang pertama dilakukan penulis, yaitu untuk menentukan objek. Kemudian dilengkapi dengan studi pustaka penelitian, hingga penulis memilih kajian organografi dan organogram kacapi indung tembang Sunda cianjuran sebagai objek dan subjek penelitian. Adapun observasi yang dilakukan penulis, adalah melakukan pengamatan langsung terhadap seorang pengrajin kacapi indung untuk mengetahui proses pembuatan dan bagianbagian kacapi indung tembang Sunda cianjuran.

d) Dokumentasi

Dokumentasi merupakan suatu hal yang perlu dilakukan untuk membantu penulis dalam mengarsipkan data, sehingga segala hal yang ditemukan dapat dinyatakan valid. Hasil dokumentasi tersebut di antaranya berupa audio (digital recorder) yang digunakan untuk merekam saat berlangsungnya wawancara, visual (photo) dibutuhkan untuk pengdokumentasian dari proses pembuatan kacapi indung, dan dokumen berupa arsip dari museum instrument musicals online (MIMO) sebagai validasi data untuk kacapi indung yang telah tercatat di museum dunia. 


\section{Teknik Analisis Data}

Berbagai data yang didapatkan perlu disaring, diklasifikasikan, ditelaah, dan direduksi, sehingga data yang akan digunakan benar-benar teruji validitas dan korelasinya dengan penelitian ini.

a) Metode Analisis

Metode yang digunakan penulis untuk menganalisis penelitian organografi dan organogram kacapi indung yaitu dengan menerapkan metode Mantle Hood. Pertama penulis memahami dan mempelajari simbol-simbol taksonomi yang telah dibuat oleh Hood, seperti sistem klasifikasi, bahan yang digunakan, cara memainkan, fungsi musik, sosiobudaya dan dekorasi. Namun, setelah dipelajari ternayata tidak ada simbol yang cocok dengan bagian kacapi indung, maka dari itu, penulis akan membuat simbol sendiri yang mengacu pada metode Hood.

Dalam sistem klasifikasi, bentuk dasar kacapi indung adalah urutan informasi yang cukup umum dalam garis $G$ - $S$ deskripsi fisik instrumental. Observasi terhadap proses pembuatan kacapi indung membantu penulis mengetahui bentuk internal dan eksternal dari instrumen. Hal tersebut akan mempengaruhi pula terhadap Sistem Dewey Decimal yang diciptakan oleh Sachs dan Hornbostel yang berupa deretan angka pada instrumen kacapi indung, sebab setiap angka yang ditulis 
mempunyai arti yang selanjutnya dibuat organogram dengan metode Mantle Hood dalam bentuk gambar sebagai simbol penyederhanaan dari bentuk sesungguhnya.

\subsection{Sistematika Penulisan}

Sistematika penulisan skripsi ini terdiri atas: Bab I Pendahuluan, yang meliputi Latar Belakang Masalah, Rumusan Masalah, Tujuan Penelitian, Manfaat Penelitian, Tinjauan Pustaka, Landasan Teori, Metode Penelitian, dan Sistematika Penulisan.

Pada Bab II dipaparkan perihal pengertian dasar kacapi dalam karawitan Sunda, dan jenis-jenis dari kacapi seperti: kacapi pantun, kacapi kawih, dan kacapi indung tembang Sunda cianjuran.

Pada Bab III memaparkan klasifikasi instrumen kacapi indung tembang Sunda cianjuran, yang terdiri atas organografi dan organogram kacapi indung berdasarkan metode Mantle Hood.

Pada Bab IV Penutup, yang terdiri atas kesimpulan dan saran. 


\section{BAB II \\ TINJAUAN UMUM}

\section{KACAPI INDUNG TEMBANG SUNDA CIANJURAN}

Pada bab II ini menjelaskan gambaran umum perihal jenis-jenis kacapi dari sudut pandang organologi yang memfokuskan pada kacapi indung tembang Sunda cianjuran sebagai objek kajian. Adapun pengertian kacapi tersebut yang meliputi jenis-jenis kacapi di antaranya: (1) kacapi pantun, (2) kacapi kawih wanda anyar, dan (3) kacapi indung tembang Sunda cianjuran.

\subsection{Pengertian Kacapi}

Kacapi adalah alat musik tradisional Sunda yang dimainkan dengan cara dipetik. Menurut Enip Sukanda ${ }^{11}$, kata kacapi memiliki dua macam makna: (1) kacapi merupakan salah satu alat musik Sunda yang memiliki dawai; (2) kacapi merupakan nama dari salah satu jenis pohon yang buahnya dapat dimakan, dengan batang tubuhnya tegak dan lurus yang tingginya mencapai 25 sampai 30 meter, dengan memiliki nama Latin Sandoricum Koecape (1996: 1-2). Namun, kacapi yang akan dibahas dalam penelitian ini adalah kacapi sebagai instrumen Sunda yang memilki dawai.

${ }^{11}$ Enip Sukanda adalah seorang seniman sekaligus akademisi Sunda. 
Nada yang dipergunakan dalam kacapi sesuai dengan sistem notasi karawitan Sunda yang terdiri atas lima nada (pentatonik) yang ditulis dengan 1 (da), 2 (mi), 3 (na), 4 (ti), dan 5 (la) terdiri atas beberapa laras ${ }^{12}$ yakni laras degung, laras salèndro, dan laras madenda. Setiap laras memiliki kesan musikal yang berbeda. Ditinjau dari susunan intervalnya, antarnada dihitung berdasarkan satuan sen (cent), seperti pada tabel di bawah ini.

1. Laras Salèndro

\begin{tabular}{|c|c|c|c|c|c|}
\hline $\mathrm{T}(\mathrm{ugu})$ & $\mathrm{S}$ (inggul) & $\mathrm{G}($ alimer $)$ & $\mathrm{P}($ anelu) & $\mathrm{L}$ (oloran) & $\mathrm{T}(\mathrm{ugu})$ \\
\hline 1 & 5 & 4 & 3 & 2 & 1 \\
\hline
\end{tabular}

${ }_{12}$ Laras merupakan istilah gamelan Jawa yang identik dengan tangga nada, scale, atau mode (Mariko Sasaki, 2007: 5). 
2. Laras Degung

\begin{tabular}{|c|c|c|c|c|c|}
\hline T(ugu) & S(inggul) & G(alimer) & $\mathrm{P}($ anelu) & L(oloran) & $\mathrm{T}(\mathrm{ugu})$ \\
\hline 1 & 5 & 4 & 3 & 2 & 1 \\
\hline
\end{tabular}

3. Laras Madenda

\begin{tabular}{|c|c|c|c|c|c|}
\hline T(ugu) & S(inggul) & G(alimer) & $\mathrm{P}($ anelu $)$ & L(oloran) & $\mathrm{T}(\mathrm{ugu})$ \\
\hline 1 & 5 & 4 & 3 & 2 & 1 \\
\hline & & & & & \\
\hline
\end{tabular}

Table 1. Interval tangga nada dari setiap laras.

(Sumber: Enip Sukanda, 1996: 19).

Selain laras, hal yang sama pentingnya yakni teknik permainan kacapi yang dimainkan dengan cara dipetik. Dalam memetik kacapi terdapat pola-pola tersendiri. Pola merupakan bentuk atau model dari cara 
memainkan kacapi. Misalnya pada kacapi indung tembang Sunda cianjuran terdapat pola tabuh yang disebut masieupan ${ }^{13}$, $_{\text {arukan }}{ }^{14}$ dan kenitan $^{15}$.

Adapun jenis-jenis kacapi yang dibagi menjadi beberapa macam sebagai berikut:

\section{Kacapi Pantun}

Kacapi pantun berasal dari Baduy Dalam. Jumlah penduduk yang tinggal di wilayah ini sekitar 12.000 orang. Mereka mendiami Desa Kanékès, Kabupaten Leuwidamar, wilayah Rangkasbitung, Banten (van Zanten, 2016: 405). Orang Baduy Dalam saat berbicara menggunakan dialek Sunda. Kepercayaan yang mereka anut yaitu Sunda wiwitan, yakni mempercayai terhadap roh nenek moyang atau para leluhur orang Sunda.

Kesenian pantun Sunda sekitar tahun 1970-an masih sering disajikan terutama pada saat panen padi. Namun, sejak tahun 1980-an mulai tergeser, dan sejak tahun 1990-an sudah jarang dimainkan karena banyak juru pantun yang telah meninggal (Mariko Sasaki, 2007: 142). Pada saat ini, di daerah Priangan hanya tersisa beberapa juru pantun yang

\footnotetext{
${ }^{13}$ Masieupan adalah salah satu motif tabuhan kacapi indung dalam tembang Sunda cianjuran.

14 Carukan adalah salah satu motif yang dominan dipetik pada kacapi rincik tembang Sunda cianjuran.

${ }^{15}$ Kenitan adalah salah satu motif yang dominan dipetik pada kacapi rimcik. Pola tabuh kenitan ini berfungsi sebagai pembawa ritmis.
} 
sudah sepuh, salah satunya Mang $\mathrm{Ayi}^{16}$, serta di zaman sekarang, untuk generasi milenial mungkin jarang yang ingin meneruskan dari kesenian pantun ini.

Kesenian pantun merupakan jenis sastra lisan yang diciptakan dan disampaikan secara lisan atau oral, baik di dalam pertunjukan seni, maupun di luar (Hustomo dalam Aji, 2006: 18). Pantun diartikan sebagai instrumen kacapi yakni "tatabeuhan nu ditabeuhna sok dijentrèng-jentrèng, bangunna siga parahu" (alat musik yang dimainkannya dengan cara dipetik, dengan bentuk seperti perahu) (Lembaga Basa dan Sastra, 1994: 357). Penyebutan kacapi pantun disebabkan fungsinya yang sering dipergunakan dalam pertunjukan pantun Sunda, yang dibawakan oleh Ki Juru Pantun. Fungsi kacapi dalam sajian pantun ini adalah sebagai pengiring dalam carita pantun ${ }^{17}$.

Keberadaan kacapi dan seniman pelakunya terdapat pada naskah kuno masyarakat Sunda yaitu Sanghyang Siksa Kandang Karesian yang dibuat pada masa pemerintahan Sri Baduga Maharaja pada tahun 1482-

${ }^{16}$ Mang Ayi adalah seorang seniman Sunda yang berasal dari Subang. Hingga saat ini ia masih berkecimpung pada dunia kesenian khususnya pada kesenian pantun.

${ }_{17}$ Carita dalam bahasa Indonesia artinya adalah cerita. Dalam bacaan pantun Baduy, kata lalakon sering digunakan sebagai ganti kata carita, seperti: Lalakon Paksi Keuling artinya Kisah Paksi Keuling. Carita pantun Sunda tidak boleh disamakan dengan pantun Melayu, yang merupakan jenis puisi pendek. Bentuk carita pantun dalam bahasa Sunda disebutnya sisindiran atau susualan (van Zanten, 2016: 405). 
1521 (Danasamita dalam Sukanda, 1996: 3). Isi dari naskah tersebut yang memberi keterangan mengenai keberadaan kacapi dan senimannya adalah:

"Hayang nyaho di Pantun ma: Langgalarang, Banyaksatra, Siliwangi, Haturwangi; prepantun tanya. Aya ta deui. Lamun urang nyeueung nu ngawayang, ngadengekeun nu ma[n]tun, nemu siksaan tina carita, ya kangkeh guru panggung ngara[n]na (Warnaen dalam Asep, 2015: 132)."

"Bila ingin tahu tentang pantun, seperti Langgalarang, Banyaksatra, Siliwangi, Haturwangi, tanyalah juru pantun. Ada lagi. Apabila kita menonton wayang, mendengarkan juru pantun, lalu menemukan pelajaran dari kisahnya, itu disebut guru panggung (Asep Nugraha, 2015: 133)."

Dalam naskah tersebut tidak disebutkan adanya alat musik kacapi, melainkan pantun. Keberadaan kacapi dianggap ada apabila menyebutkannya dengan istilah pantun. Menurut Satjadibrata dalam Sukanda, kacapi dengan pantun sudah merupakan perpaduan yang tak dapat dipisahkan, sehingga dalam peribahasa Sunda ada yang berbunyi: kawas pantun teu jeung kacapi (Ind. seperti pantun tanpa kacapi) (1996: 3). Adapun pendapat Ayip Rosidi terhadap pantun yaitu: (1) kacapi yang bentuknya seperti perahu; (2) carita pantun yaitu cerita yang mengisahkan zaman kerajaan Pajajaran; (3) juru pantun yaitu seorang juru cerita yang 
melakonkan cerita pantun yang diiringi petikan pantun (kacapi parahu) sambil dinyanyikan (1996: 3).

Fungsi dari kesenian pantun itu sendiri terdapat tiga macam yaitu (1) pantun yang berfungsi sebagai hiburan, (2) pantun yang berfungsi sebagai upacara ruatan, dan (3) pantun yang sering disajikan pada upacara panen padi (netepkeun pare). Pantun untuk hiburan biasanya dipertunjukkan dalam rangka perayaan dan syukuran (seperti syukuran rumah dan bayi lahir). Pantun untuk upacara ruwatan khusus bagi manusia atau benda yang ingin diruat, yang bertujuan agar tidak terjadi malapetaka atau kesialan. Dalam prosesi upacara ruwatan ini peran juru pantun sangat penting sebagai mediator untuk berkomunikasi kepada roh leluhur. Prosesi dimulai dengan memainkan kacapi pantun sambil membakar kemenyan, dan harus disediakan sesaji kepada leluhur. Sedangkan, pantun untuk upacara padi seperti bentuk rasa syukur akan hasil panennya. Pelaksanaan upacaranya pun malam hari setelah menyimpan padi ke dalam lumbung (goah atau leuit) (Atik Soepandi dan Enoch Atmadibrata, 1983: 20).

Struktur cerita pantun pada umumnya tidak banyak berubah, yaitu: (1) kisah di sekitar kerajaan Pajajaran, (2) peran utamanya dikisahkan 
dimulai dari lahir sampai diangkat menjadi raja, (3) peran utamanya mengalami proses inisiasi, (4) selalu dibarengi dengan supranatural berupa penghuni alam kahyangan baik para rahyang (dewa-dewa) maupun para pohaci dengan ratunya (Sunan Ambu atau Wiru Mananggay), dan (5) adanya pembantu yang sangat dekat dengan pemeran utama yang berwatan kocak yang disebut Lengser (Sukanda dalam Pepep, 2012: 64). Struktur di atas dalam pementasannya dibawakan oleh seorang laki-laki (juru pantun). Juru pantun tersebut saat membawakan cerita pantun mengiringi sendiri dengan petikan instrumen kacapi.

Bentuk fisik dari kacapi pantun berukuran kecil serta hampir menyerupai seperti perahu. Panjangnya antara 70-80 cm, lebar 15-20 cm, dan tinggi 12-15 cm (Suryana, Soepandi, dan Ekadjati dalam Asep, 2015: 134), dengan jumlah dawai 6 - 12 utas yang berbahan kawat.

Bahan utama kacapi yaitu terbuat dari kayu (tidak disebutkan jenisnya) dan memiliki lubang resonator di bagian bawah yang berfungsi sebagai keluarnya gelombang suara dari instrumen tersebut. Untuk mengatur nada, dibuatkanlah kayu yang berbentuk piramid yang disebut dengan inang. 
Selain inang, ada juga pureut (tuning peg) yaitu kayu yang dijorokkan ke dalam badan kacapi, lalu ujung pureut dililitkan dengan ujung dawai (setiap satu pureut yakni satu dawai) dengan fungsi yang sama yaitu sebagai pengatur nada.

Selanjutnya, tumpang sari yang berfungsi sebagai penyangga dawai yang diikatkan pada baut. Posisi dari tumpang sari berderetan ke samping (menyerong) yang mengikuti panjang dari dawai tersebut. Dimulai dari yang terdekat dengan pemain hingga dawai terakhir yang paling jauh.

Wangkis adalah atas kotak resonator atau kayu yang dijadikan alas inang. Wangkis berfungsi sebagai sumber penghantar getaran dari dawai untuk menghasilkan suara. Wangkis sendiri merupakan bagian yang paling penting dalam instrumen kacapi. Bahan yang digunakan untuk bagian wangkis yakni jenis-jenis kayu yang lembut dan empuk agar menghasilkan getaran suara yang baik, seperti kayu kananga dan albasiah (wawancara, Desmon; 08 April 2019). Pemilihan jenis kayu untuk membuat wangkis dapat mempengaruhi karakter suara kacapi. Apabila kayu yang digunakan terlalu keras (padat) maka suara yang dihasilkan tidak akan sesuai dengan kebutuhan musikal (wawancara dengan Desmon, 08 April 2019). 


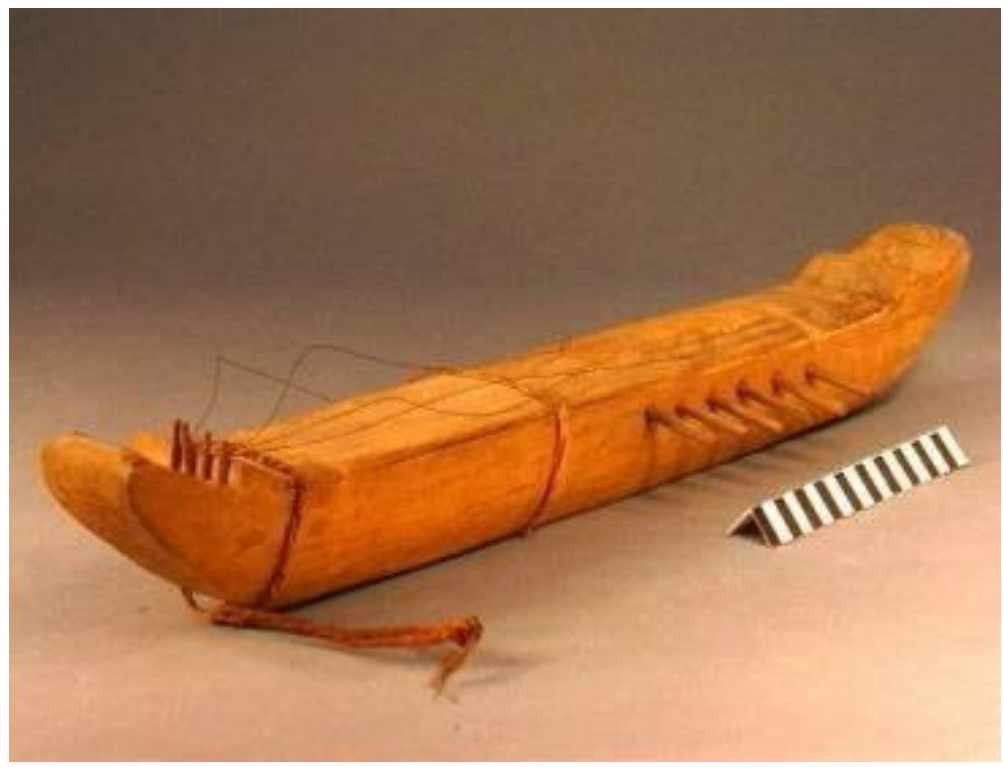

Gambar 3. Kacapi sebelum tahun 1894.

(Sumber: Digital Collection Leiden, 2016-2019). 


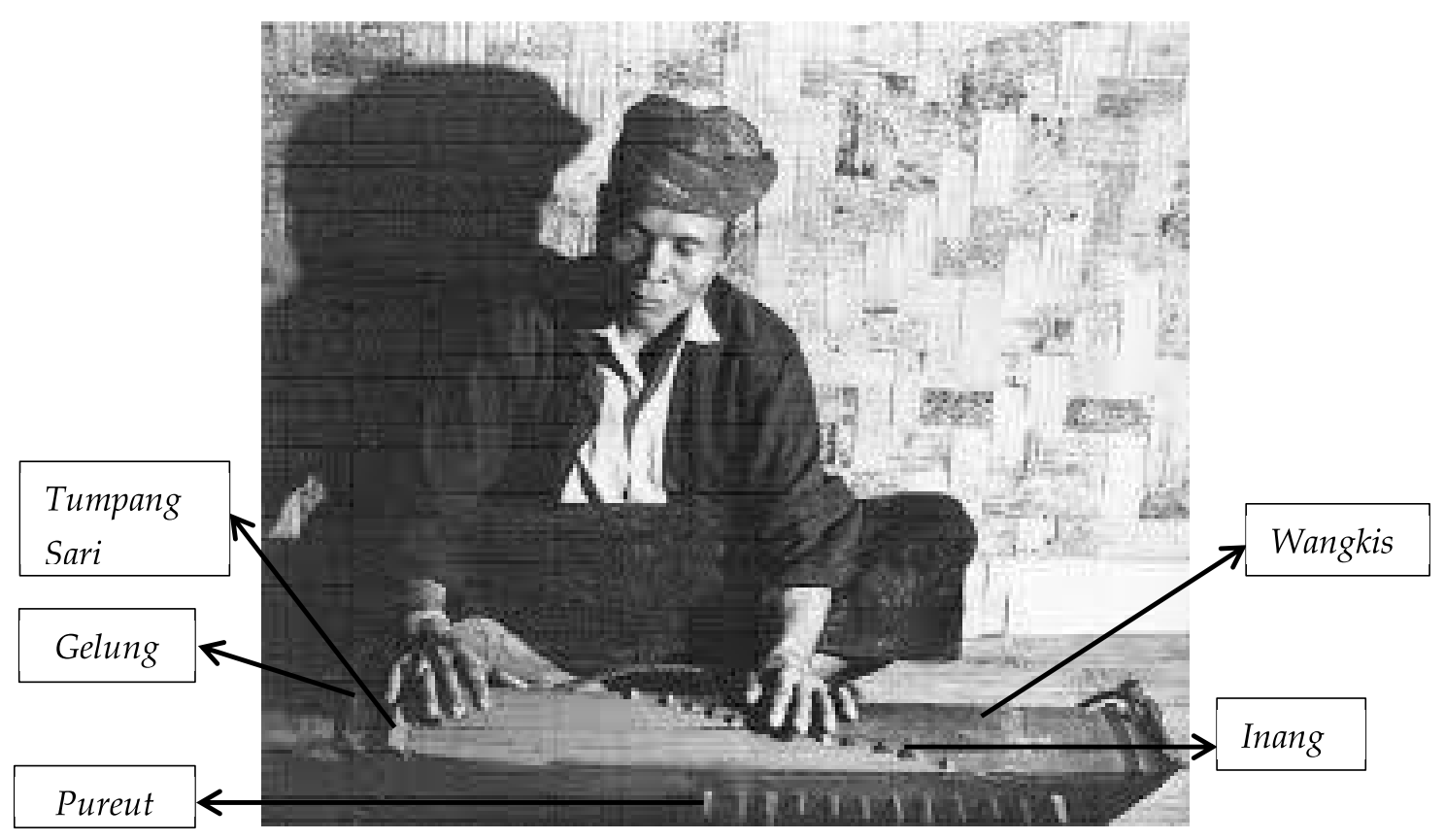

Gambar 4 . Pemain kacapi pantun dari Cikadu, Kanékès, tahun 1976. Kacapi yang dimainkan memiliki 12 dawai

(Sumber: Wim van Zanten, 2016: 417).

\section{Kacapi Kawih Wanda Anyar}

Kawih wanda anyar merupakan salah satu genre kesenian Sunda yang

berkembang di Jawa Barat. Kawih wanda anyar pertama kali dicetuskan oleh seorang maestro karawitan Sunda yang bernama Koko Koswara, yang oleh masyarakat Sunda lebih dikenal dengan julukan Mang Koko. Banyak karya Mang Koko yang dikenal oleh masyarakat Jawa Barat, hingga dibuatlah sebuah perlombaan kawih wanda anyar yang diikuti oleh berbagai kalangan dari anak-anak hingga dewasa. 


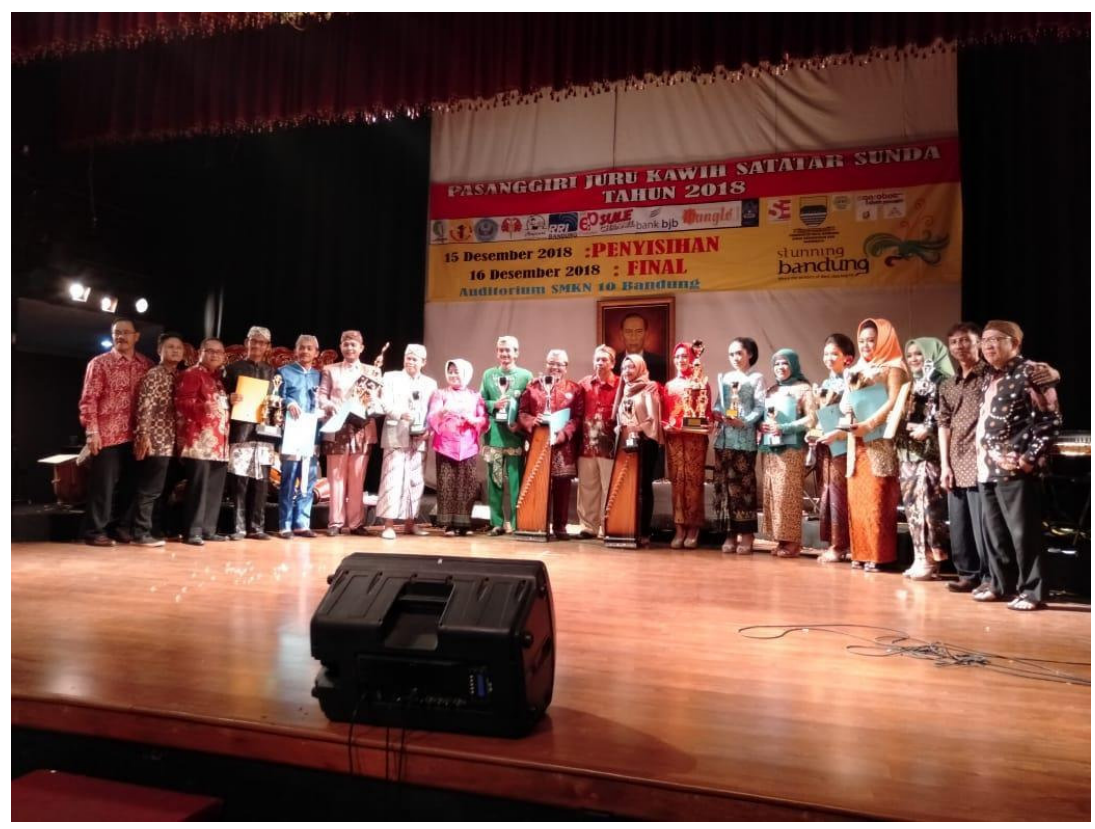

Gambar 5. Pasanggiri Juru Kawih Satatar Sunda, yang dilaksanakan pada tanggal 16 Desember tahun 2018, di SMK 10 Bandung.

(Sumber: dok. Sri Ningsih, 2019).

Kawih wanda anyar karya Mang Koko ini berkembang pesat dan dikenal masyarakat Jawa Barat sejak tahun 1950-an. Karya Mang Koko dalam dunia pentas banyak menarik perhatian publik, ditambah lagi ia mengajar di salah satu sekolah seni yaitu KOKAR (Konservatori Karawitan) atau SMKI (Sekolah Menengah Karawitan Indonesia) yang sekarang lebih di kenal dengan SMK 10 Bandung (Tardi Ruswandi, 1995: 3-5). Selain itu, Mang Koko memasyarakatkan kacapi kawih (kacapi siter) ke seluruh Jawa Barat karena dia berhasil menciptakan lagu-lagu dan gending-gending (aransemen musik) Sunda dalam bentuk baru, yang kemudian diberi nama lagu-lagu wanda anyar. Lagu yang dciptakan Mang 
Koko dengan jumlah yang tidak sedikit disebarkan melalui Yayasan Cangkurileung bersama dengan Kanwil DIKBUD JABAR dan dibuatlah perlombaan serta penataran kepada guru-guru sekolahan (Sukanda, 1996: 11).

Dalam kawih wanda anyar, kacapi merupakan instrumen yang dominan, dan memiliki teknik petikan tersendiri. Teknik-teknik petikan kacapi kawih wanda anyar tersebut diciptakan oleh Mang Koko. Motif-motif petikannya dilatarbelakangi oleh musikalitas Koko ketika masa kanak-kanak hingga remaja, yang akrab dengan pendidikan Belanda berikut musiknya (Nugraha, 2015: 139). Maka dari itu, sungguh tidak heran apabila motif yang ia ciptakan banyak dipengaruhi oleh motif musik Barat, seperti “arpeggio" (akor yang dimainkan secara berurutan) dan irama "mars".

Apabila ditinjau dari bentuknya, kacapi kawih wanda anyar sama dengan kacapi yang terdapat dalam kesenian jenaka Sunda dan celempungan , dimana kacapi tersebut berbentuk kotak persegi panjang dengan jumlah dawai sebanyak 20 utas. Berikut adalah gambar dari kesenian jenaka Sunda dan celempungan dengan kacapi yang serupa pada kesenian kawih wanda anyar. 


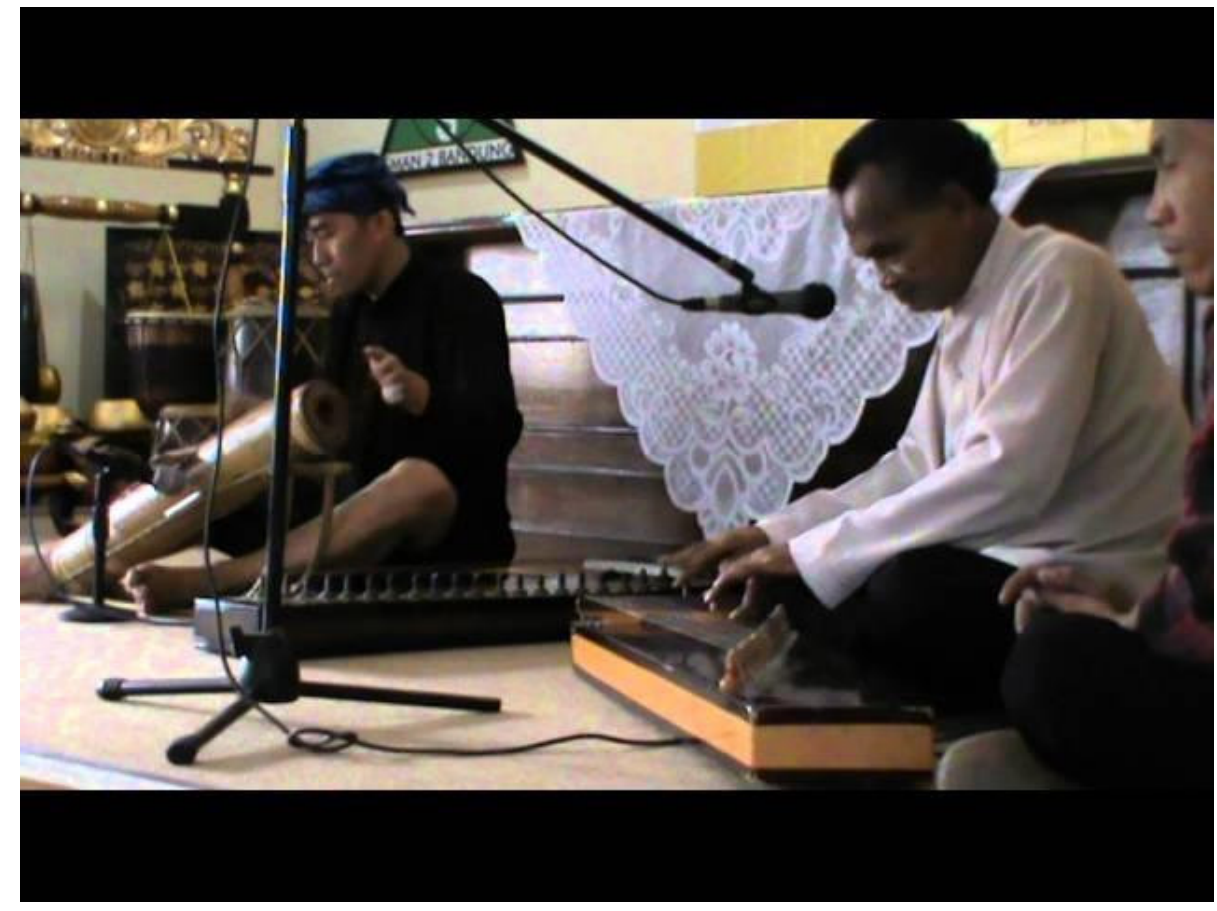

Gambar 6. Penampilan kesenian celempungan yang menggunakan kacapi kawih atau siter (sumber: Youtube, Khidhir Kuskus, 2014). 


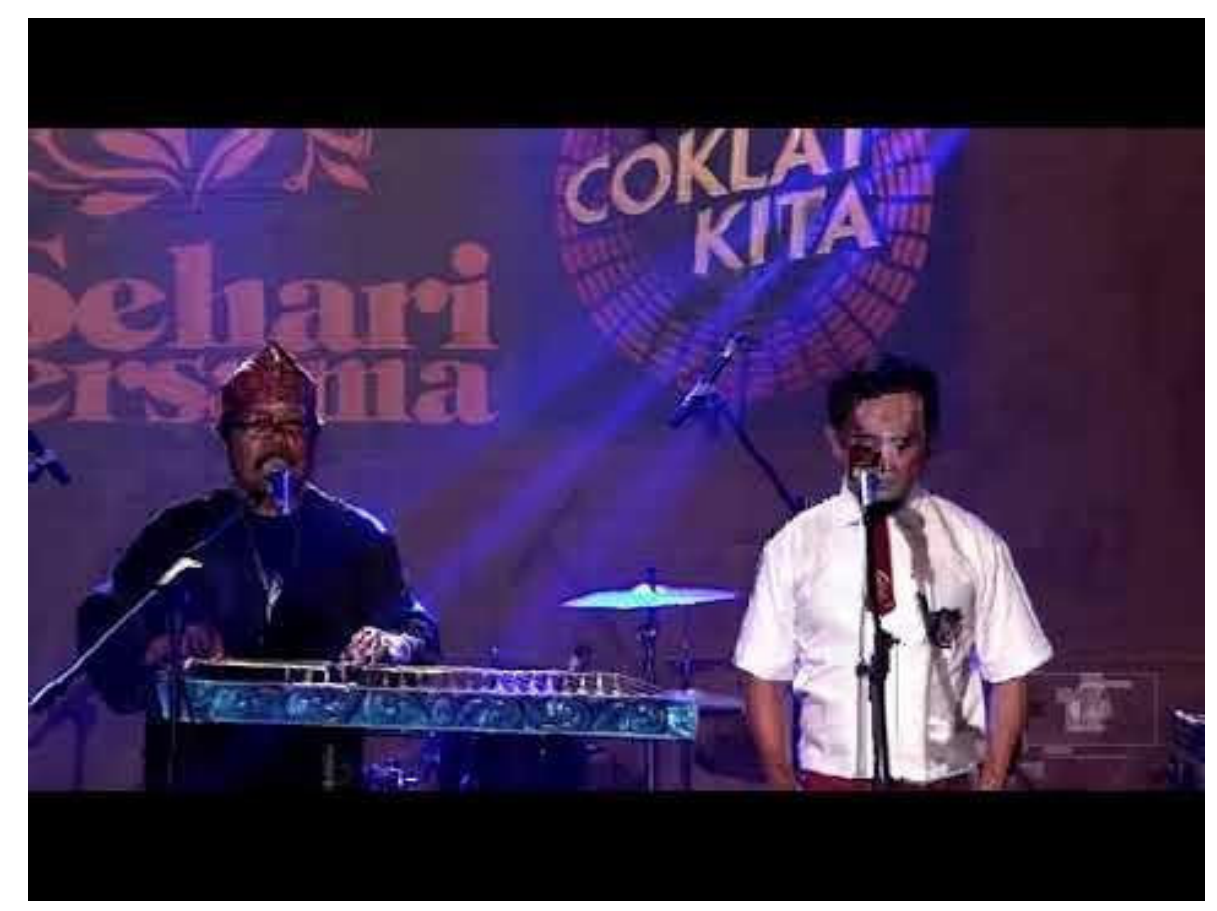

Gambar 7. Penampilan kesenian jenaka Sunda dengan kacapi yang berjumlah dawai 20 utas (sumber: Blog baixar, 2017)

Penyebutan kacapi kawih wanda anyar dilihat berdasarkan fungsi dari instrumen tersebut yaitu digunakan untuk mengiringi sajian kawih wanda anyar. Dalam sajian kawih wanda anyar terdiri dari beberapa instrumen yang mendukung di antaranya: kacapi, suling, rebab, goong dan kendang.

Jika dilihat dari bahannya, kacapi kawih tidak jauh beda dengan kacapi pantun. Bahan pokok yang digunakan pun hampir sama yaitu kayu, hanya saja jenis kayunya saja yang berbeda. Contohnya kayu yang 
digunakan untuk pembuatan kacapi kawih yakni kayu albasiah, manglid, mindi, atau mahoni.

Pembuatan kacapi kawih diawali dari proses pengukuran terlebih dahulu. Dimulai dari mengukur panjang, lebar, tinggi, dan ketebalan (untuk ruang resonator), sebagai berikut:

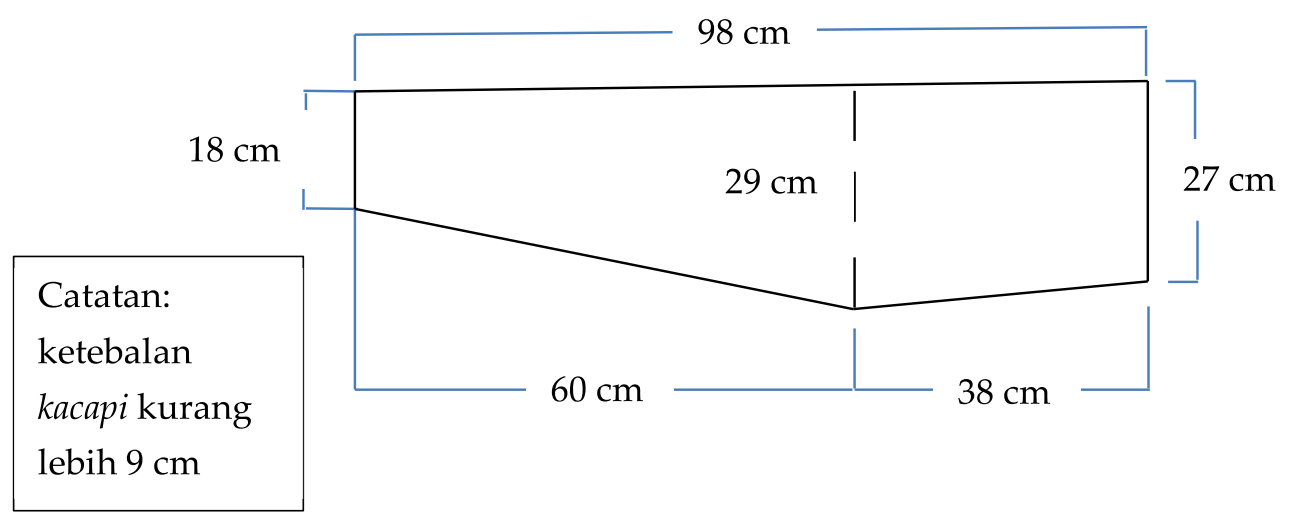

Gambar 8. Sketsa ukuran kacapi kawih.

(Sumber: Desmon, 2019).

Selanjutnya jenis dawai yang digunakan pada instrumen kacapi kawih terdiri atas 3 (tiga) macam yaitu: (1) dawai pilastro atau kawat gitar yang terbesar untuk nada-nada terendah dawai 20 - 16; (2) dawai kuningan untuk nada-nada sedang atau di bagian tengah dawai 15 - 9; dan (3) dawai baja perak untuk nada-nada tinggi dawai 8 - 1 (Kubarsah, 1994: 22). 


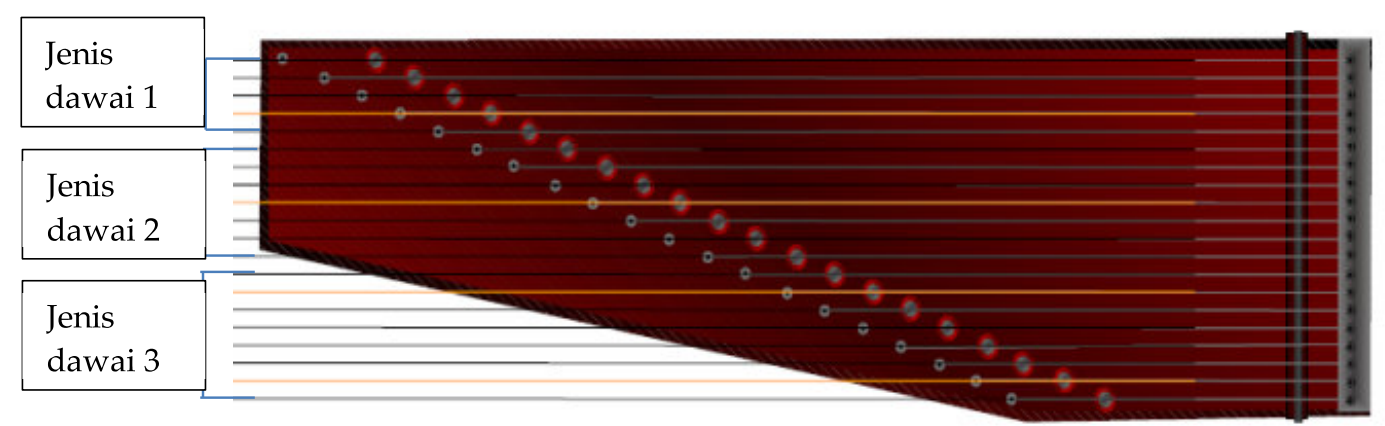

Gambar 9. Kacapi kawih; berdasarkan jumlah dawai dan jenis dawai. (Sumber: Wikipedia, 2019).

Adapun bagian-bagian kacapi kawih lainnya dengan penamaan yang hampir sama dengan kacapi tembang, seperti inang, tumpangsari, mata itik, wangkis, dan resonator, yang membedakan adalah bentuknya. Contohnya bentuk inang pada kacapi kawih dan kacapi tembang. Akan tetapi, jika dilihat dari fungsi tetap sama yaitu sebagai pengatur nada (selain pureut atau tuning peg). 


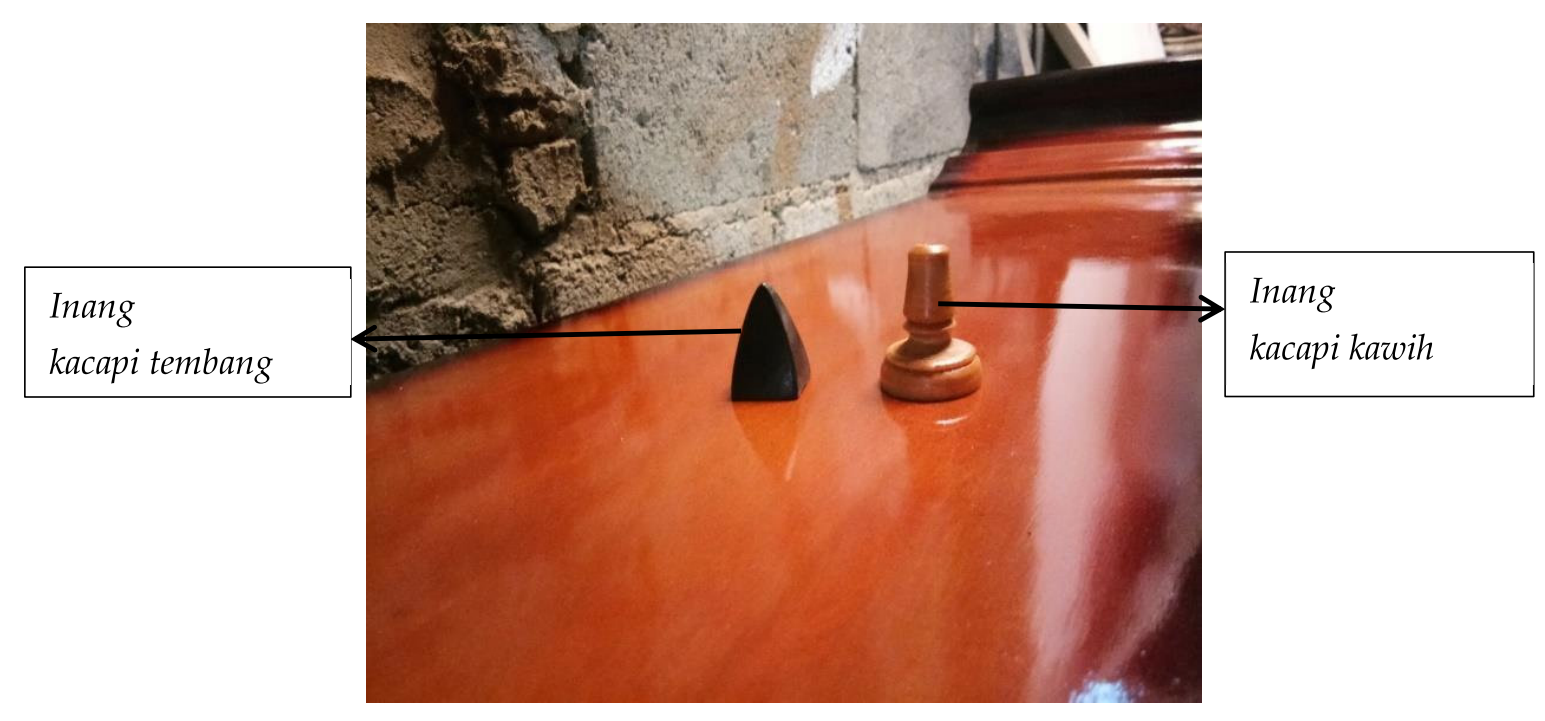

Gambar 10. Inang kacapi tembang seperti piramid dan inang kacapi kawih seperti anak catur.

(Sumber: dok. Pribadi, 2019).

Apabila dilihat secara keseluruhan bagian-bagian kacapi kawih wanda anyar adalah sebagai berikut:

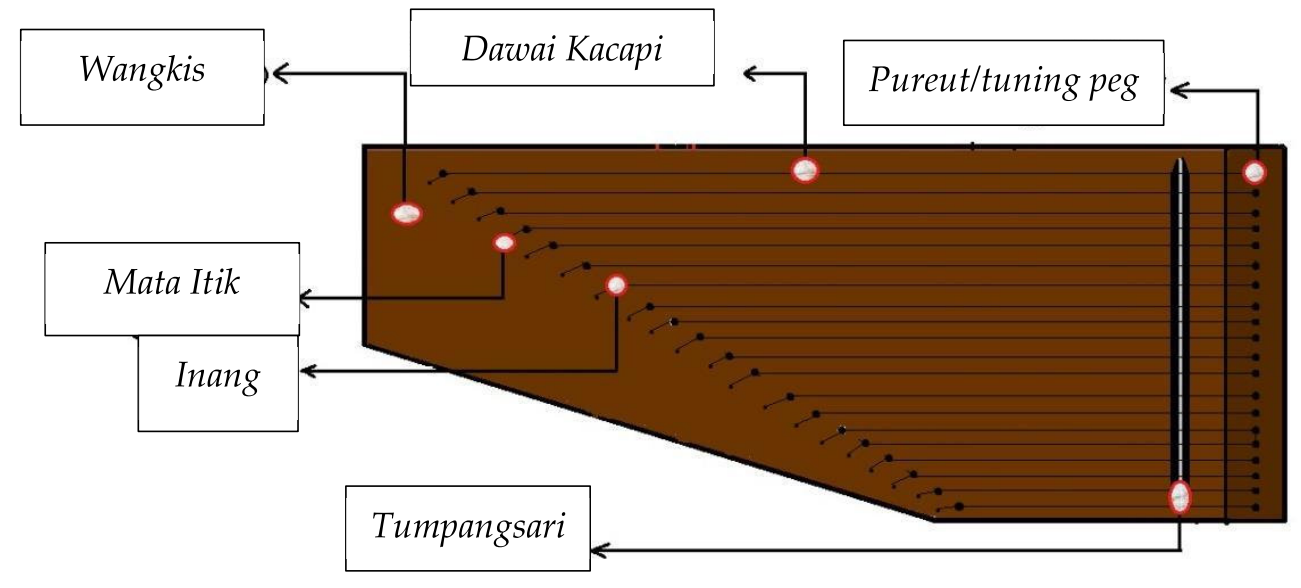

Gambar 11. Kacapi kawih tampak atas.

(Sumber: Tedi Nur Rohmat, 2012). 


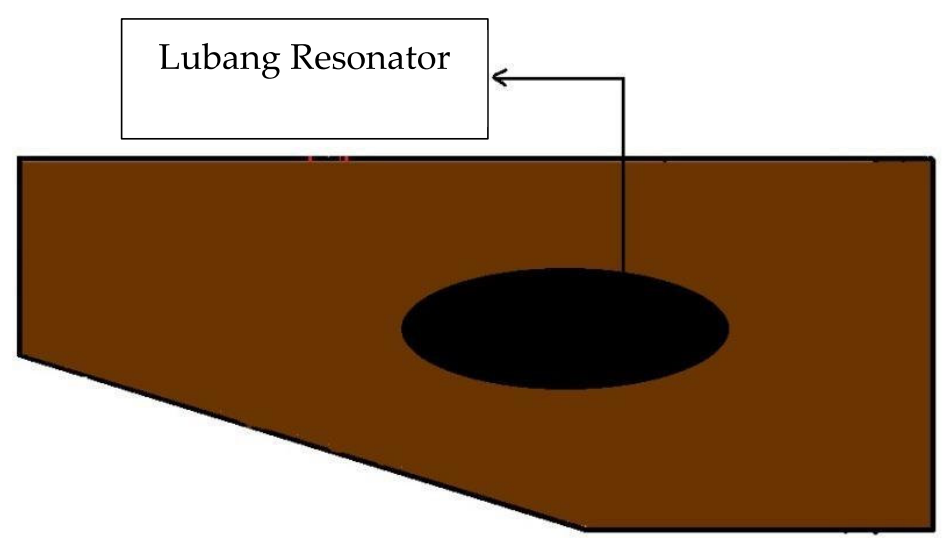

Gambar 12. Kacapi kawih tampak bawah; bagian resonator. (Sumber: Tedi Nur Rohmat, 2012).

Kesederhanaan bentuk dari kacapi kawih memudahkan orang dalam membuatnya, itulah sebabnya mengapa kacapi kawih lebih banyak beredar di masyarakat untuk dimanfaatkan, baik secara pribadi maupun kelompok kesenian. Kacapi kawih dapat dikatakan sebagai instrumen yang cukup ringan dan mudah dibawa kemana-mana; dengan kata lain ekonomis dan praktis, seperti halnya gitar. Bentuk kacapi kawih yang tipis, pendek, dan ringan dapat dimanfaatkan dalam situasi apa saja. Begitupun bagi orang yang baru belajar kacapi, pada umumnya diawali dengan menggunakan kacapi jenis kawih/siter ini. 
Akan tetapi, untuk menarik perhatian banyak orang, pengrajin diuji kreativitasnya yakni dengan menambahkan dekorasi pada instrumen. Contohnya dengan diberi ukiran (nama atau gambar) pada kacapi tersebut. Dengan demikian, kreativitas pengrajin sangat diperlukan. Contohnya dapat dilihat pada gambar di bawah ini.

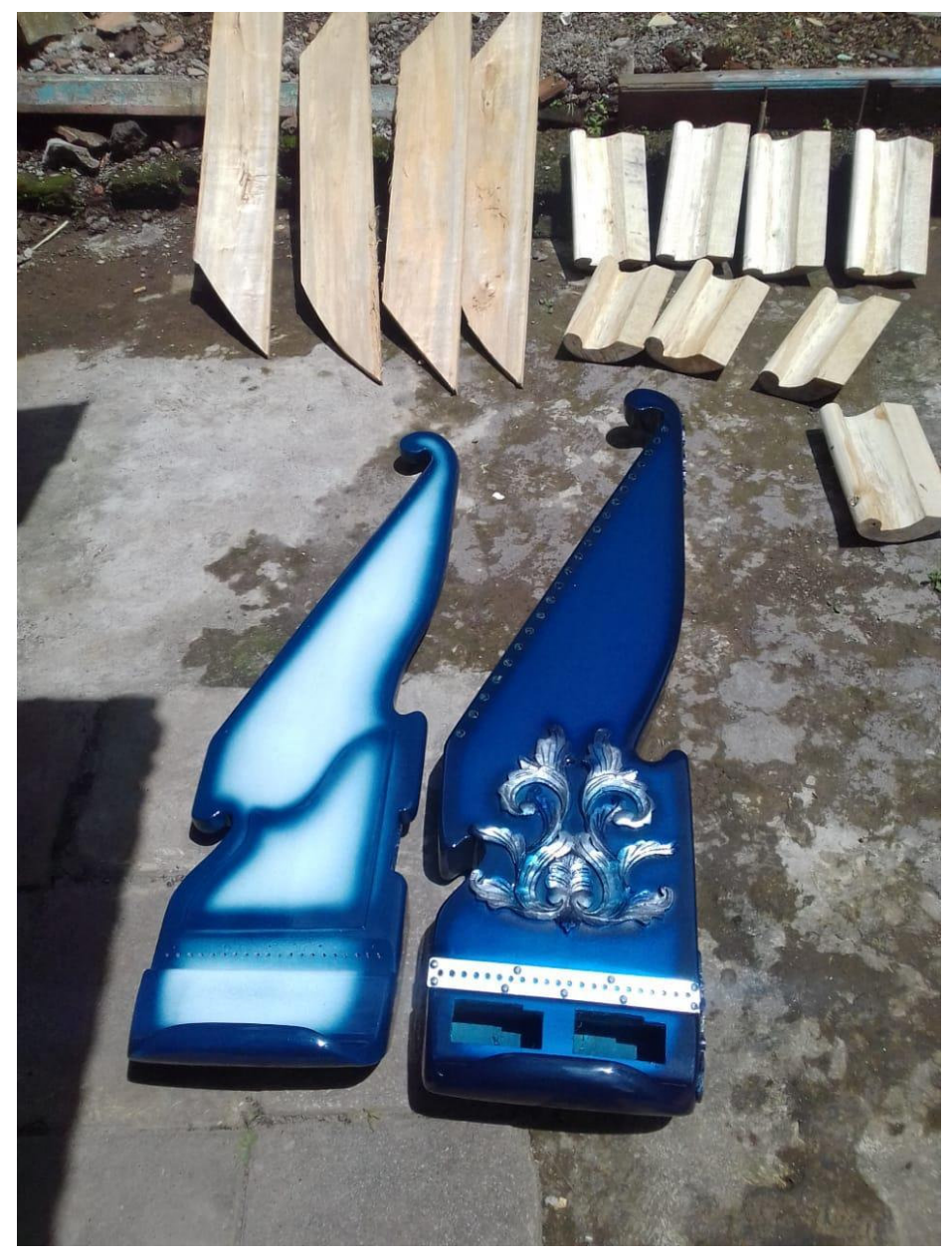

Gambar 13. Koleksi kacapi buatan Desmon (sumber: dok. Pribadi, 2019). 


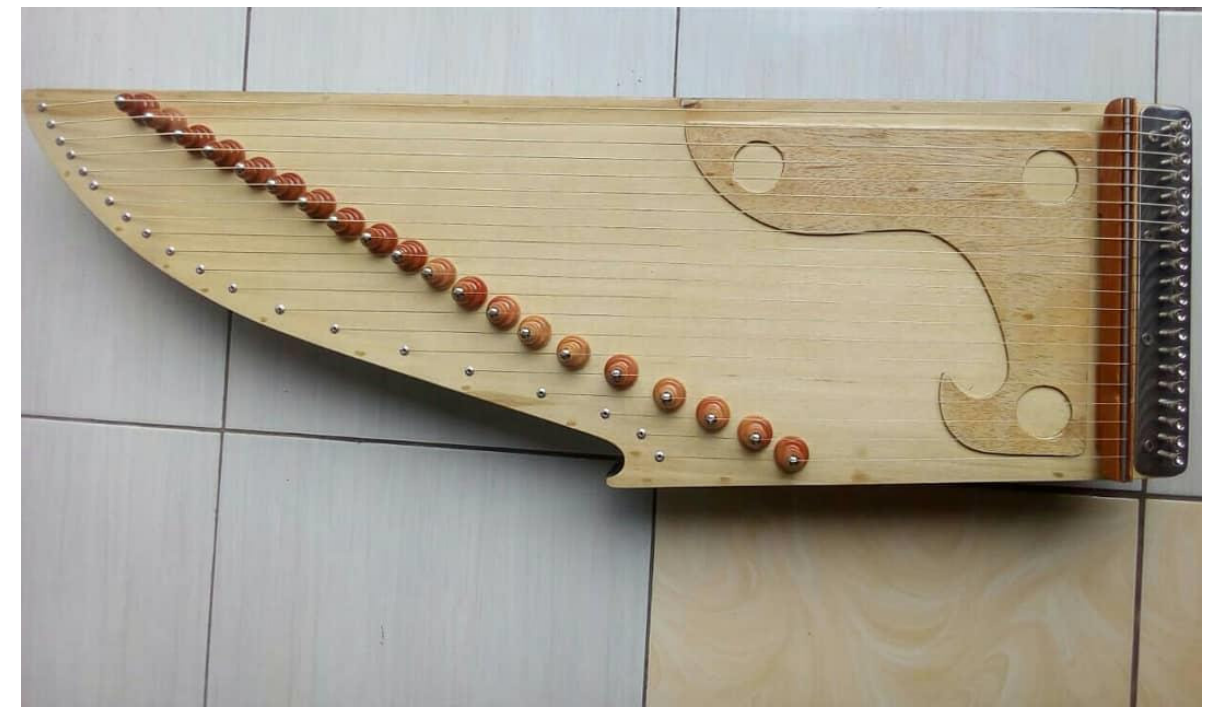

Gambar 14. Kreativitas pengrajin dengan ditambahkannya dekorasi dan bentuk yang unik (sumber: dok. Musiktradisional Sunda. Deskgram.net, 2018).

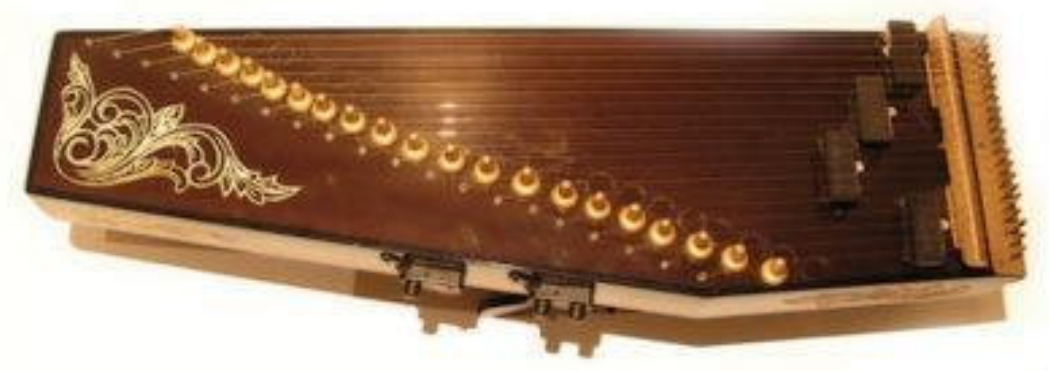

Gambar 15. Kacapi dengan diberi ukiran pada bagian atas (sumber: dok. Ahmad Saepudin, 2015). 
Posisi pemain kacapi kawih cukup beragam, ada yang duduk di lantai, memakai stand (ancak) seperti keyboard (piano) yakni sambil berdiri atau duduk di kursi, dan ada pula yang memainkannya dengan cara disimpan di pundak layaknya mengangkat anak kecil, lalu dipetik tanpa melihat ke dawai yang dimainkan (melalui feeling). Namun itu semua tergantung dari konsep pertunjukan yang dibutuhkan. Lazimnya yang sering digunakan yakni duduk di lantai dengan dua kaki bersila atau duduk di kursi menggunakan stand keyboard.

\section{Kacapi Indung Tembang Sunda Cianjuran}

Tembang Sunda cianjuran adalah kesenian Sunda yang menggunakan instrumen kacapi indung, kacapi rincik, suling, dan atau rebab. Instrumen pokok pada kesenian tembang Sunda cianjuran yakni kacapi indung atau sering disebut juga dengan kacapi tembang karena sesuai dengan fungsinya yakni untuk mengiringi pertunjukan tembang Sunda cianjuran.

Penamaan tembang Sunda cianjuran telah dikukuhkan pada tahun 1962 ketika diadakan musyawarah Tembang Sunda sa-Pasundan di Bandung (Dika Dzikriawan, 2017: 25). Masyarakat kini lebih mengenalnya dengan tembang Sunda cianjuran, meskipun masih ada beberapa seniman yang 
menyebutnya dengan mamaos. Berdasarkan kajian Enip Sukanda, Moh.

Kosasih Atmadinata, dan Dadang Sulaeman dalam Dzikriawan bahwa:

Proses penciptaan tembang Sunda cianjuran mencapai puncaknya pada 1840-an. Pada waktu itu, yang menjadi Bupati di Cianjur adalah R.A.A. Kusumaningrat atau lebih dikenal dengan sebutan Dalem Pancaniti yang memerintah pada 1834-1864. Dalam periode ini, tembang Sunda cianjuran disuguhkan sebagai seni hiburan khususnya untuk kaum bangsawan di lingkungan kabupaten Cianjur, sementara kalangan orang biasa tidak diperbolehkan untuk menikmati jenis kesenian ini. Nama asli kesenian ini adalah mamaos (2017: 25).

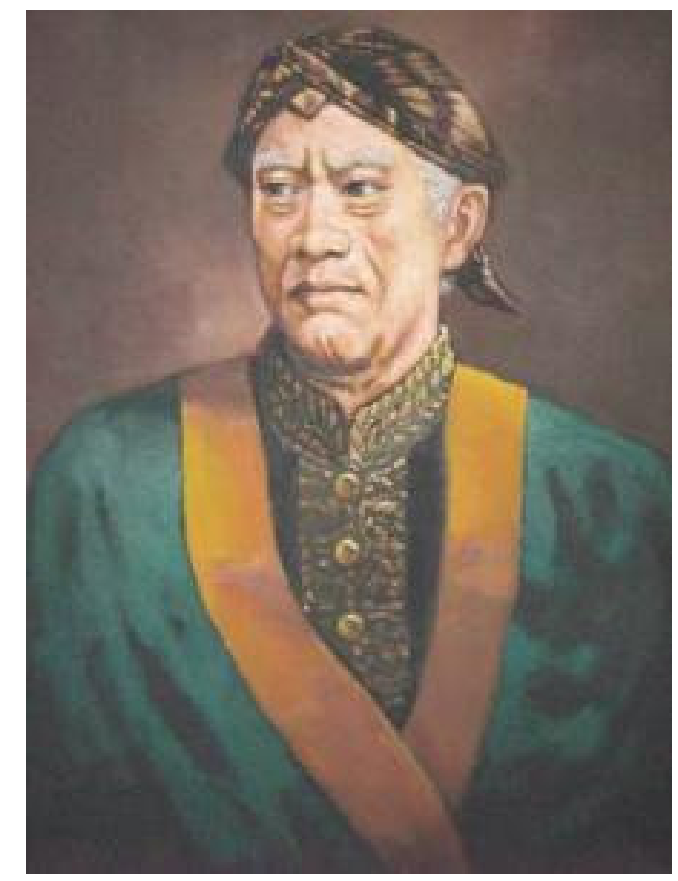

Gambar 16. R.A.A. Kusumaningrat (sumber:

http://cianjuranku.blogspot.com/2015/12/pahlawan-cianjuran.html?m=0, 2015). 
Bupati Cianjur yakni Raden Aria Adipati (R.A.A.) Kusumaningrat (1834-1864), atau yang dikenal dengan sebutan Dalem Pancaniti, mempunyai sebuah kacapi indung atau kacapi tembang yang memiliki sebutan khusus yaitu Nyi Pohaci Guling Putih. Penamaan kacapi tersebut melambangkan aspek penghormatan terhadap Dewi Padi. Kacapi Nyi Pohaci Guling Putih dibuat putih alami (warna kayu asli) tanpa pewarna, dengan bahan kayu yang terbuat dari kayu cempaka putih (Michelia Alba) (Enip Sukanda, 1996: 6-7). Proses pembuatan kacapi tersebut dengan cara ditatah seperti membuat lesung. Adapun papan tempelan hanya pada bagian atasnya (wangkis).

Bahan baku instrumen kacapi tembang Sunda cianjuran terdiri atas: kayu, kawat, dan paku. Bahan tambahan antara lain, cat atau pelitur. Jenis kayu yang digunakan dalam pembuatan kacapi tembang yakni jenis kayu kananga. Kayu tersebut digunakan untuk membuat bagian inti kacapi yaitu resonator (wadah gema). Selanjutnya, kayu tersebut dibuat untuk pureut (tuning peg), tumpang sari, dan inang yang berfungsi untuk menaikturunkan nada, serta gelung yang terdapat pada kedua sisi kacapi. Ukuran dari kacapi panjangnya antara $135-150 \mathrm{~cm}$, lebarnya antara $24-26 \mathrm{~cm}$, dan tingginya sampai gelung sekitar $40 \mathrm{~cm}$, sedangkan tinggi kotak suara (vertikal) kira-kira 21 cm (Sukanda, 1996: 6). 
Jenis dawai yang digunakan terbuat dari logam kuningan, tembaga atau baja yang memiliki berbagai ukuran. Ada empat macam ukuran dawai kuningan yakni: (1) ukuran $0,8 \mathrm{~mm}$ (milimeter) untuk suara terbesar; (2) 0,6 mm untuk suara tengah; (3) 0,5 mm untuk suara terendah; dan (4) 0,4 untuk nada-nada tertinggi yang dekat dengan posisi pemain (Ubun Kubarsah, 1994: 12). Jumlah dawai terus bertambah seiring berjalannya waktu, dari 9, 11, 15 dawai, hingga sekarang berjumlah 18 utas dawai.

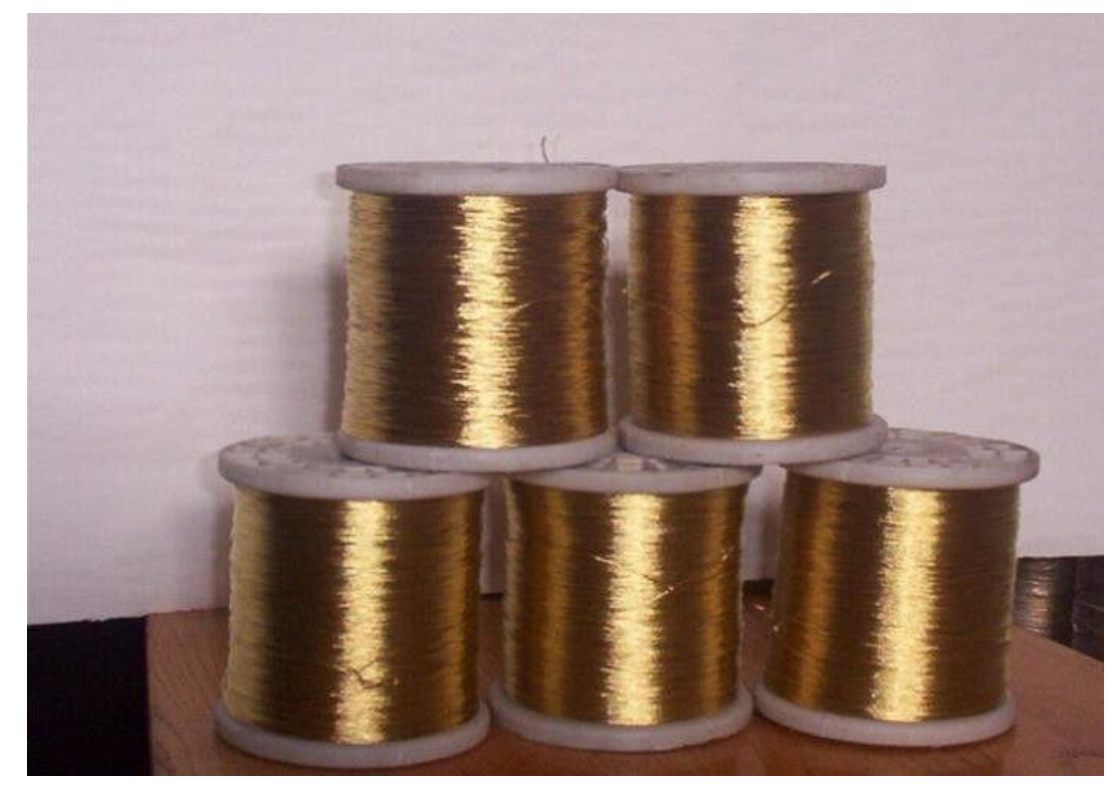

Gambar 17. Kawat kuningan yang dominan dipakai pada instrumen kacapi indung tembang Sunda cianjuran.

(Sumber: Indonesian.wirenettingfence.com, 2017). 
Paku yang digunakan yaitu paku yang biasa dipakai oleh tukang bangunan. Fungsi paku tersebut yaitu untuk memaku dalam pembuatan resonator, mengaitkan, dan menggulung dawai yang ditancapkan pada bagian kacapi. Penggunaan paku berawal dari pembuatan kacapi dengan cara papan yang disambung sehingga membentuk kacapi indung tembang Sunda cianjuran. Jika proses pembuatannya dengan cara ditatah, akan memakan waktu yang cukup lama. Sedangkan, memakai paku bisa dikatakan efektif dan efesien dalam pengerjaannya (Wawancara, Desmon, tanggal 08 April 2019).

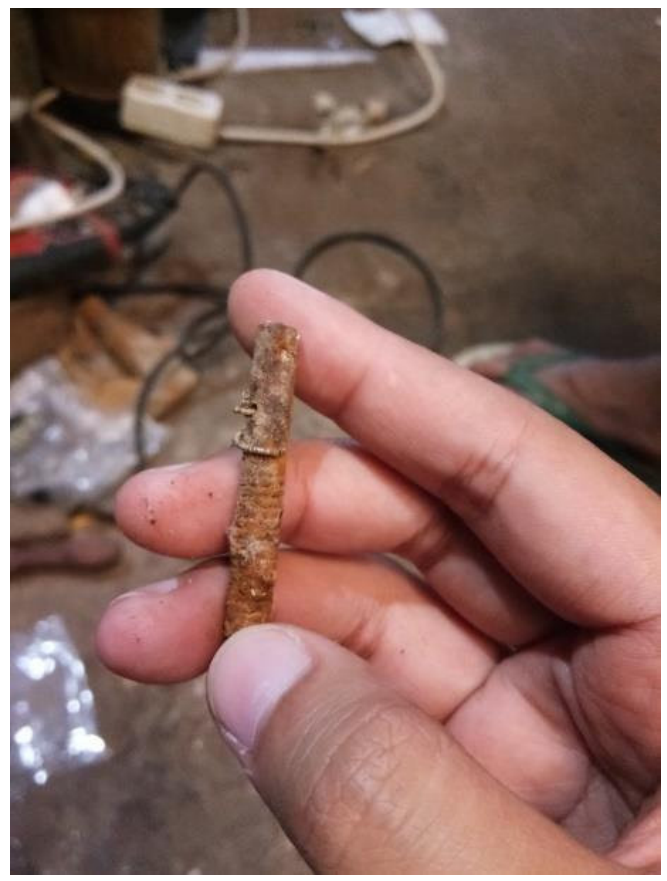

Gambar 18. Merupakan baut untuk mengaitkan dawai. (Sumber: dok. Pribadi, 2019). 


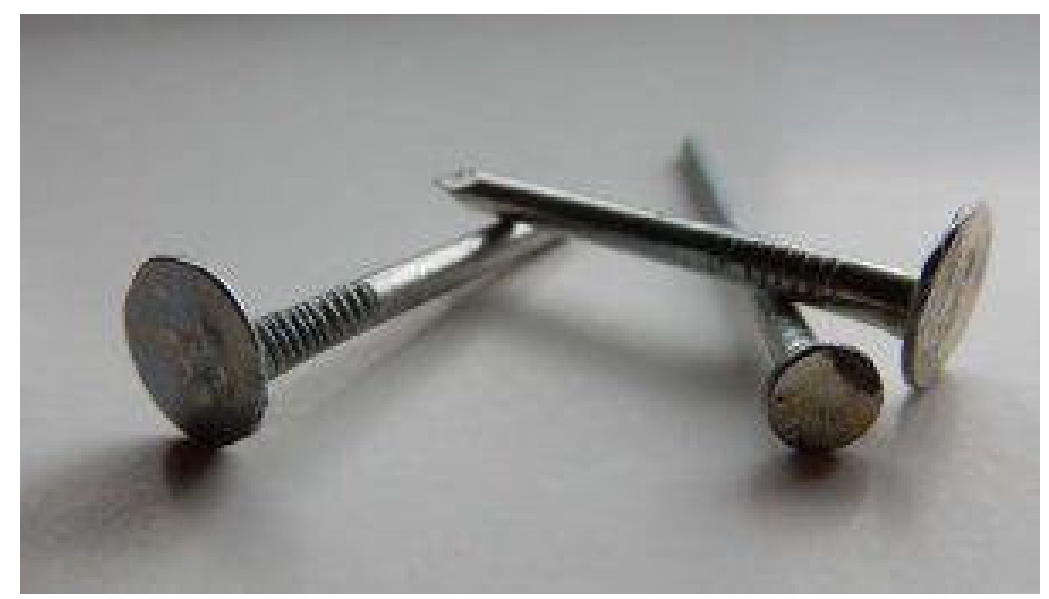

Gambar 19. Paku yang digunakan untuk membuat kacapi. (Sumber: hargamaterial.com, 2017).

Adapun bahan tambahan lain yaitu cat atau pelitur. Cat digunakan pada bagian luar kacapi. Warnanya disesuaikan dengan kehendak pemilik kacapi. Warna yang dominan digunakan yaitu hitam. Selain itu ada pula warna lainnya seperti: coklat, merah bata, dan hijau tua (Sukanda, 1996: 7).

Berdasarkan penjelasan di atas, ada satu hal yang tidak boleh dilewatkan yaitu bagian mata itik yang diletakkan pada bagian ujung kacapi, yang berfungsi melapisi lubang-lubang dawai agar tekanan dawai tidak langsung kepada wangkis. Kegunaan lain dari mata itik adalah untuk menahan tegangan dawai yang masuk ke dalam lubang-lubang kayu. Apabila tidak menggunakan mata itik, kayu (wangkis) tidak akan tahan 
lama dan akan terbelah karena gesekan dari getaran dawai tersebut (wawancara Desmon, pada tanggan 29 Maret 2018). Kacapi indung yang memakai mata itik masih terbilang jarang akan tetapi, jika di lihat dari fungsinya dapat digunakan untuk mengantisipasi dari kerusakan instrumen dalam jangka waktu yang cukup lama.

Di antara bagian-bagian kacapi tembang yang telah disebutkan di atas, yang menjadi ciri khas dari kacapi tembang itu sendiri adalah pada bagian gelung. Gelung merupakan dekorasi dari kacapi tembang yang memiliki daya tarik. Apabila dilihat secara estetika, memang indah dan unik, sebab berbeda dengan kacapi pantun dan kacapi kawih wanda anyar yang tidak memiliki gelung.

Posisi pemain dalam memainkan instrumen kacapi tembang ini yakni duduk di lantai dengan dua kaki bersila. Akan tetapi, ada pula yang memakai stand keyboard (ancak). Penggunaan ancak dalam kesenian tembang Sunda cianjuran belum begitu lazim dikalangan masyarakat umum, namun sering dilihat pada saat pertunjukan Tugas Akhir di kampus ISBI Bandung. 


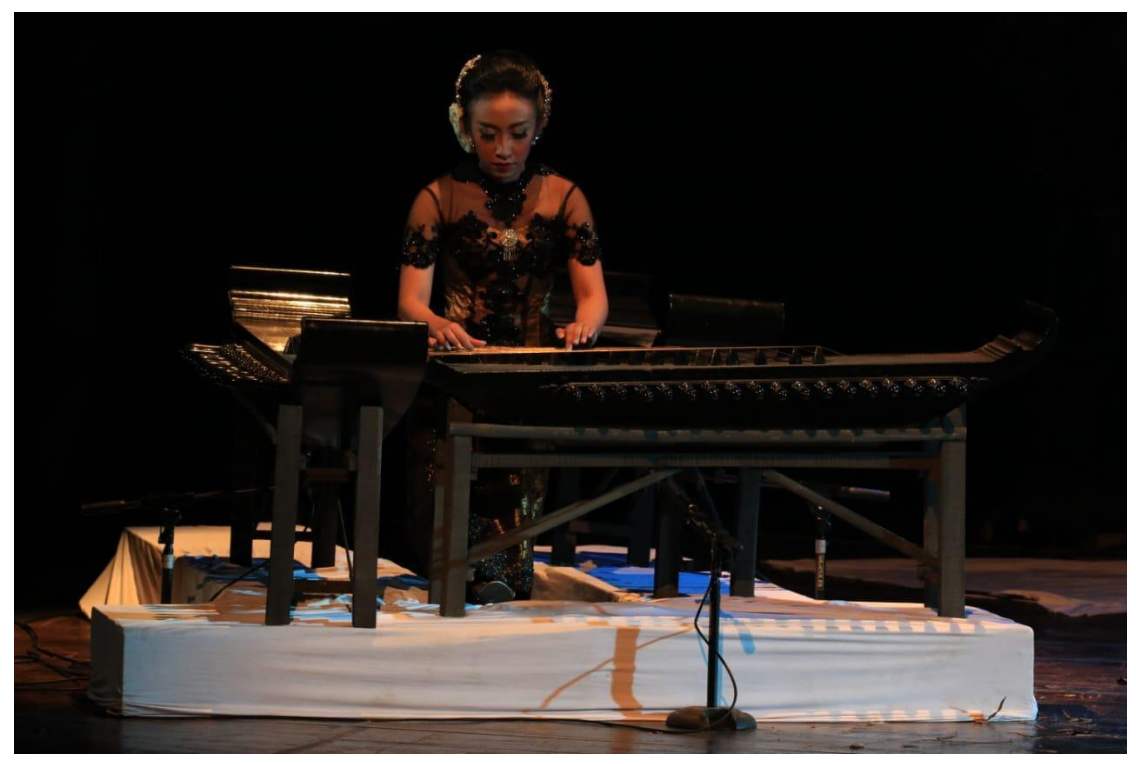

Gambar 20. Pemain kacapi indung memakai stand saat

Tugas Akhir di ISBI Bandung.

(Sumber: dok. Jheinita Ayu Pratami, 2014).

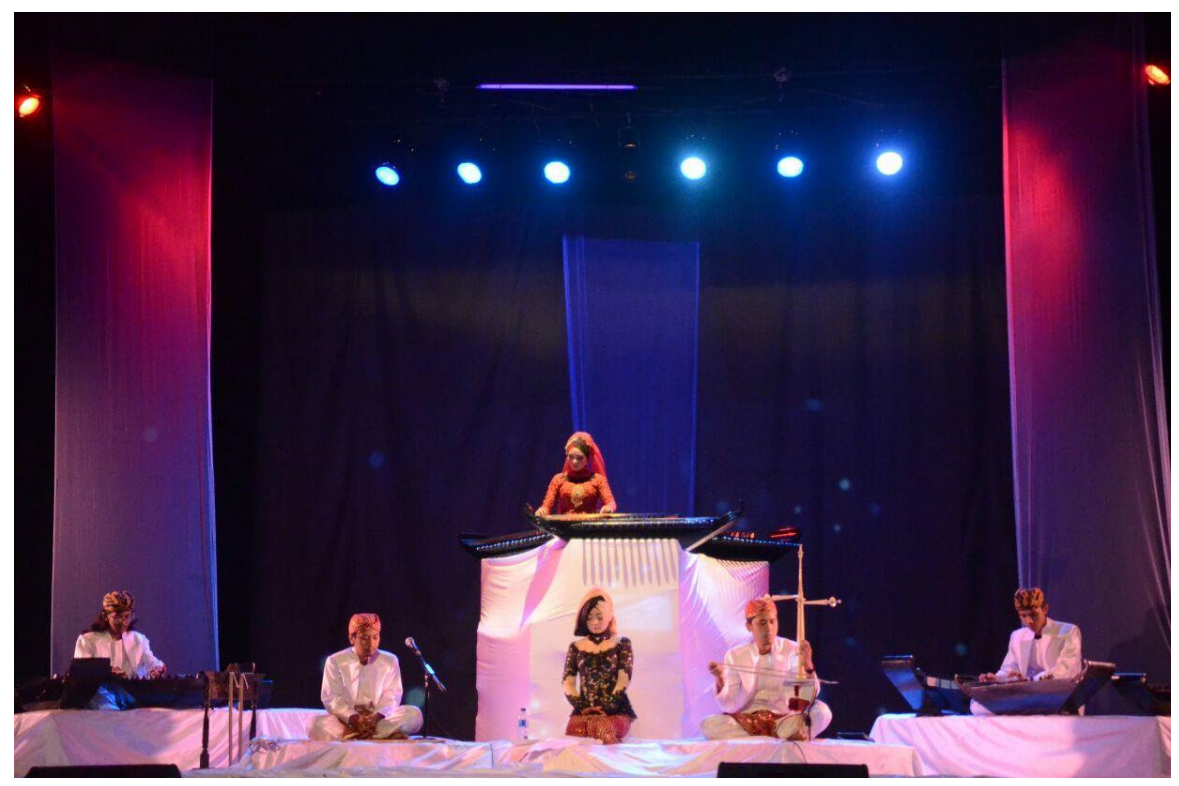

Gambar 21. Pertunjukan tembang Sunda cianjuran, dengan instrument kacapi indung yang memakai stand dengan ditutupi kain.

(Sumber: dok. Karnanda, 2012). 
Hal tersebut bukan menjadi sebuah persoalan, sebab posisi pemain kacapi itu sendiri ditentukan sesuai dengan konsep pertunjukan yang disajikan oleh pemain. 


\section{BAB III}

\section{ORGANOGRAFI DAN ORGANOGRAM KACAPI INDUNG}

\subsection{Sekilas tentang Organologi}

Organologi merupakan bidang ilmu yang mempelajari bagian-bagian pada alat musik dan termasuk ke dalam subbagian dalam studi etnomusikolgi. Organologi berasal dari kata organ yang berarti benda, alat, atau barang dan logi (asal kata logos) yang artinya adalah ilmu (Kriswanto dalam Herman, 2012: 10). Jadi secara sederhana organologi adalah ilmu yang mempelajari tentang benda atau alat.

Di antara banyak definisi organologi menurut para ahli, penulis mengambil satu sudut pandang yakni menurut Mantle Hood. Dalam bukunya, Mantle Hood mendefinisikan bahwa organologi adalah suatu bidang ilmu pengetahuan yang mempelajari tentang struktur instrumen musik dan sejarah, akan tetapi sama penting dengan aspek-aspek lainnya seperti teknik pertunjukan, fungsi musik, dekorasi, dan sosio-budaya dari instrumen (1971: 124). Sehingga, pembahasan mengenai organologi cukup luas dengan dilihat dari berbagai aspek yang telah dipaparkan oleh 
Mantle Hood. Hal tersebut akan diterapkan pada instrumen kacapi indung dengan menggunakan sudut pandang organologis Mantle Hood.

\subsection{Klasifikasi Instrumen Kacapi Indung}

Definisi klasifikasi menurut Kamus Besar Bahasa Indonesia (KBBI) yakni penyusunan bersistem dalam kelompok atau golongan menurut kaidah atau standar yang ditetapkan. Terkait dengan sebuah pengklasifikasian terhadap instrumen, maka definisi klasifikasi yang dimaksud yakni sebuah pengkategorian instrumen musik yang dikelompokkan berdasarkan kelas yang telah ditentukan.

Tercatat dalam literatur bahwa telah ditemukan sistem klasifikasi instrumen musik di 3 (tiga) wilayah budaya yang mengembangkan taksonomi untuk alat musik. Ketiga wilayah budaya tersebut adalah: Cina Kuno, India, dan Eropa. Klasifikasi pada wilayah budaya Cina Kuno berlandaskan pada suatu sistem yang disebut sistem bayin yang berarti delapan bunyi yaitu: logam (chi), batu (shih), tanah liat (t'u), kulit (ko, sutra (ssu), labu ( $\left.p^{\prime} a o\right)$, bambu (chu), dan kayu (mu) (1982: 124). Klasifikasi instrumen musik ini merupakan sebuah sistem instrumen yang paling tua yang pernah ada dalam sejarah kebudayaan dunia. 
Menurut Irwansyah Harahap, klasifikasi instrumen musik di wilayah budaya India, seperti disebut dalam buku India kuno, yaitu kitab Nãtyaśãstra, dibagi menjadi empat kelompok: (1) ghana vãdya (alat musik yang tergolong padat, seperti lonceng atau simbal), (2) avanadha vadya (alat musik yang tertutup atau ditutupi oleh membran, seperti gendang), (3) tata vãdya (alat musik yang menggunakan dawai), dan (4) susira vadya (alat musik yang memiliki rongga udara, seperti alat tiup) (2005: 30). Keempat pengelompokkan alat musik ini dibedakan berdasarkan karakteristik fisik bunyi, yakni dari sumber bunyi, tingkat kepadatan, serta adanya rongga atau lubang di bagian tertutup pada alat musik.

Klasifikasi instrumen musik yang terakhir yaitu pada wilayah budaya Eropa. Perkembangan pada klasifikasi instrumen musik, yang awal mulanya hanya terdapat tiga pengklasifikasian yaitu strings (dawai), wind (angin) dan percussion (perkusi), dikembangkan oleh Victor Mahillon (seorang kurator instrumen musik di Museum Instrument Conservatory di Brussel, Belgia) dan diperjelas kembali oleh seorang etnomusikolog bernama Curt Sachs dan Erich Moritz von Hornbostel.

Sachs dan Hornbostel menyadari akan perkembangan musik klasik dalam orkestra, dimana setiap alat musik mempunyai keunikan tersendiri saat dimainkan. Sehingga, pengelompokkan yang sebelumnya telah 
dibuat, mereka kembangkan sesuai dengan perkembangan alat musik pada saat itu. Adapun skema klasifikasi instrumen beserta pengembangannya adalah sebagai berikut:

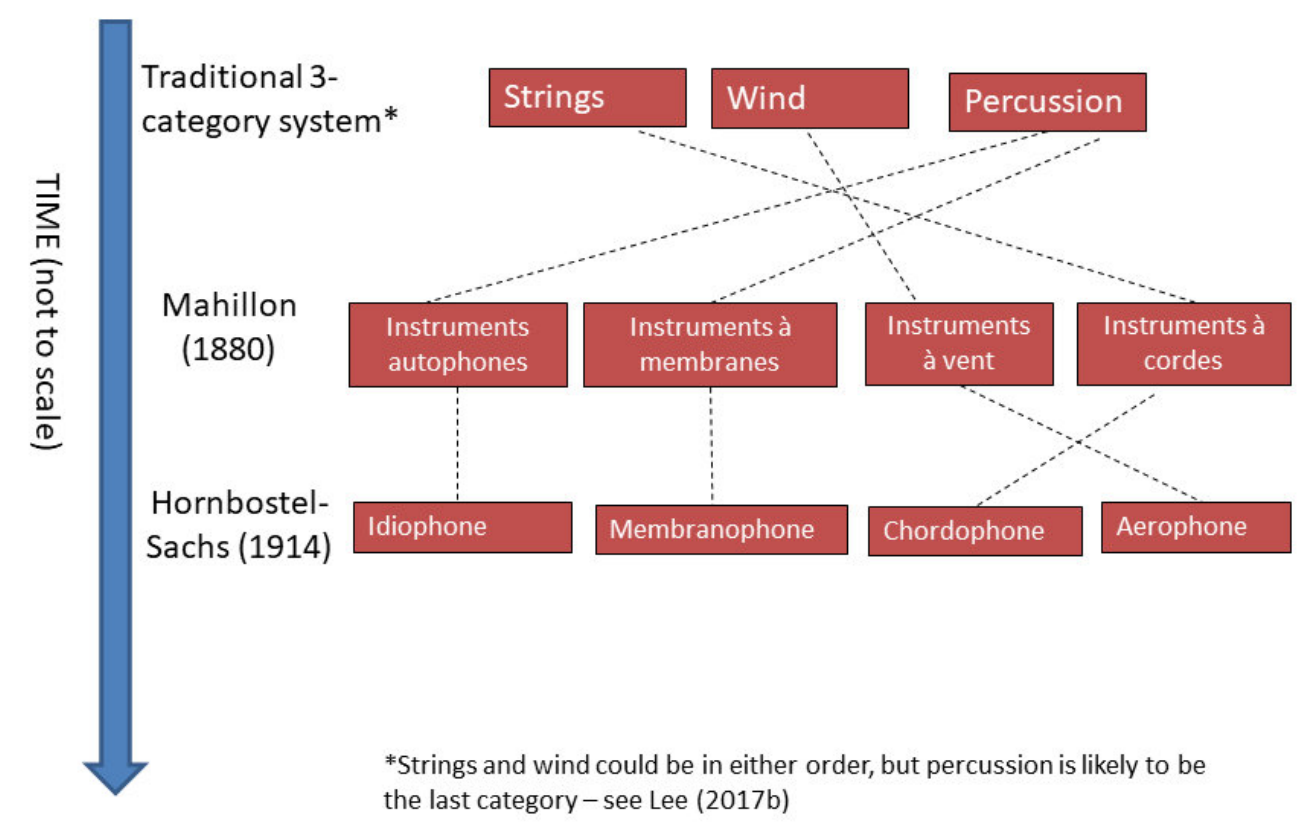

Gambar 22. Perkembangan klasifikasi instrumen musik Sachs dan Hornbostel. (Sumber: Deborah Lee. ISKO, 2019).

Pengklasifikasian yang dibuat oleh Sachs dan Hornbostel pertama kali dipublikasikan pada tahun 1914 di Zeitschrift für Ethnologie dan versi bahasa Inggris dipublikasikan pertama kali pada Galpin Society Journal tahun 1961 (Upaja Budi, 2015: 147). Sistem klasifikasi Sachs dan 
Hornbostel terdiri atas empat golongan, yakni (1) idiophone yaitu instrumen yang sumber bunyinya dihasilkan berdasarkan getaran alat musik itu sendiri; contoh adalah simbal, gong, bel, dan balok kayu, (2) membranophone yaitu instrumen dengan sumber bunyi yang dihasilkan dari getaran kulit atau membran yang diregangkan; contoh adalah drum, kendang, dan rebana, (3) chordophone yaitu instrumen dengan sumber bunyi yang dihasilkan dari getaran dawai yang diregangkan antara dua titik; contoh adalah gitar, ziter, lut, dan harpa, dan (4) aerophone yaitu instrumen dengan sumber bunyi yang dihasilkan dari kolom udara; contoh flut, terompet, suling, dan clarinet. Namun, Jaap Kunst ${ }^{18}$ memberikan tambahan untuk klasifikasi musik yakni electrophones. Electrophones yaitu instrumen dengan sumber bunyi yang dihasilkan dari daya listrik. Ia beralasan bahwa studi musik berkembang terus dan mencakup dunia musik non-Barat (Sri Hendarto, 2011: 8). Klasifikasi yang dibuat oleh Sachs dan Hornbostel telah dikenal serta dipakai oleh para etnomusikolog dan kurator museum dunia untuk mengelompokkan instrumen musik.

\footnotetext{
${ }^{18}$ Jaap Kunst adalah etnomusikolog Belanda yang merupakan salah satu pendiri etnomusikolog modern (https://www.britannica.com/biography/Jaap-Kunst diakses pada tanggal 15 Juni 2019 pukul 23.20 WIB).
} 
Pada tahun 2011, MIMO (Musical Instrument Museums Online) merevisi sistem klasifikasi Sachs dan Hornbostel. Versi MIMO merupakan sebuah revisi yang substansial. Dapat dilihat pada gambar berikut:

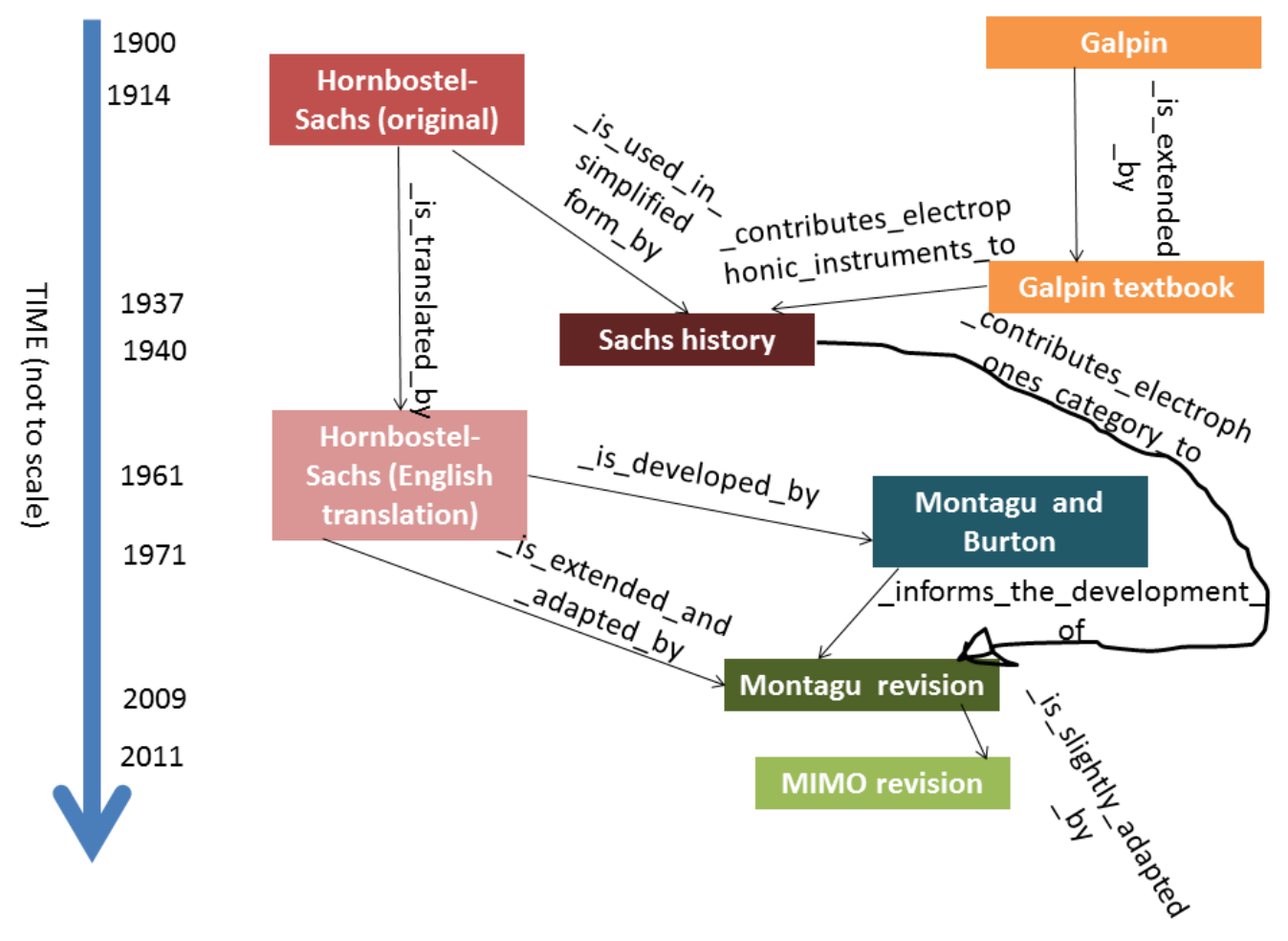

Gambar 23. Hubungan antara versi MIMO Sachs dan Hornbostel dan antesedennya, termasuk penambahan elektrofon.

(Sumber: Deborah Lee. ISKO, 2019).

Pada gambar di atas terdapat 2 (dua) versi pengklasifikasian musik, yakni yang dibuat oleh Galpin dan Sachs-Hornbostel. Adanya pengadaptasian dan pengembangan versi yang berbeda-beda setiap 
tahunnya, yang ditunjukkan oleh arah anak panah ke bawah. Sehingga, terciptalah sebuah klasifikasi instrumen musik yang telah direvisi oleh MIMO 2011, yang merupakan sebuah pengadaptasian dari revisi Montagu tahun 2009.

Sejumlah ahli telah merevisi atau memperbaiki versi Sachs dan Hornbostel menjadi versi MIMO, seperti yang dilakukan oleh seorang ahli organologi yang bernama Jeremy Montagu. Ia merevisi sebuah klasifikasi instrumen musik dengan didasari pada versi yang telah dilakukan sebelumnya.

Apabila dikaitkan dengan pengklasifikasian instrumen musik Sachs dan Hornbostel revisi MIMO, instrumen musik kacapi indung dapat digolongkan ke dalam klasifikasi chordophone. Hal tersebut dapat diuraikan berdasarkan dari sumber bunyi yang dihasilkan oleh dawai yang direntangkan di antara dua titik, dengan terbatasnya pada faktorfaktor akustik.

\section{Dewey Decimal System Sachs - Hornbostel}

Penjelasan secara detail terhadap sebuah instrumen musik tidak cukup dengan mengklasifikasikan berdasarkan sumber bunyi. Sachs dan Hornbostel menemukan sebuah cara untuk mempermudahnya yaitu 
dengan menggunakan sebuah sistem yang diberi nama DDS (Dewey Decimal System) dengan cara pemberian nomor pada klasifikasi instrumen musik. Sistem ini merupakan pengadopsian dari suatu ilmu DDC (Dewey Decimal Classification) yang diciptakan oleh Melvil Dewey ${ }^{19}$. Tujuan dari dibuatnya sistem DDC adalah untuk mengklasifikasikan subjek dan notasi koleksi bahan pustaka yang wujud jadinya berupa deretan angka dimana bentuknya berupa katalog. Margaret $\mathrm{Kartomi}^{20}$ menyatakan sebagai berikut: ". . . However, it is not advisable to think of the Hornbostel dan Sachs scheme as being comparable to Dewey's classification system for library books; the similarity is only apparent initially. The Hornbostel dan Sachs scheme uses as varying set of criteria to distinguish its various subcategories under the main taxa (taxonomy: by writer), while the Dewey system applies a single author and subject across the board" (1990: 168)

${ }_{19}$ Melville Louis Kossuth Dewey (1851-1931) atau dikenal juga dengan nama Melvil Dewey [Dui] (1851 - 1931), menemukan sistem DDC (Dewey Decimal Classification) ketika berusia 21 tahun dan bekerja sebagai asisten mahasiswa di perpustakaan Amherst College, Amerika. Pada tahun 1876, Dewey membantu mendirikan ALA (American Library Association). Pada tahun 1883, Dewey bekerja sebagai pustakawan di Columbia College (sekarang Columbia University) di New York City; dan pada tahun 1887 ia mendirikan sekolah perpustakaan pertama di dunia yang berlokasi di Universitas itu (https://www.oclc.org/en/dewey/resources/biography.html diunduh pada tanggal 11 April 2019).

${ }^{20}$ Margaret Joy Kartomi lahir tanggal 24 November 1940 di Adelaide, Australia. Margaret Kartomi adalah seorang ahli musik dan etnomusikolog dari Universitas Adelaide dan Humbolt, Australia. Sejak tahun 1988 sampai sekarang ia menjadi seorang professor musik di Universitas Monash (http://www.harmonies.com/biographies/kartomi.htm diunduh pada tanggal 10 Mei 2019, 23.41 WIB). 
“ . . Namun, tidak disarankan untuk berpikir bahwa skema Hornbostel dan Sachs sebanding dengan sistem klasifikasi Dewey yang digunakan pada buku perpustakaan; kemiripan angka kodifikasi hanya tampak pada awalnya. Skema Hornbostel dan Sachs menggunakan serangkaian kriteria yang berbeda untuk membedakan dari berbagai subkategori di bawah taksa (taksa yang dipersepsikan penulis adalah taxonomi) utama, sementara sistem Dewey menerapkan satu nama penulis dan subjek yang disimpan secara bersilangan pada papan kodifikasi angka."

Pengadopsian sebuah sistem yang digunakan Sachs dan Hornbostel bukan menjadi sebuah persoalan, karena skema yang dibuat oleh Sachs dan Hornbostel tentunya dilatarbelakangi oleh beberapa aspek yang mendukung, seperti aspek akustik, morfologi, linguistik dan lain sebagainya. Di dalamnya termasuk parameter historis dan sosial. Dengan demikian, Dewey Decimal System yang dibuat Sachs dan Hornbostel wujud jadinya berupa deretan angka-angka. Hal tersebut menjadi sebuah alternatif atau cara untuk mendeskripsikan sebuah instrumen musik.

Parker, dalam Margaret (1990: 168), mengatakan bahwa klasifikasi Dewey Decimal System adalah sistem hierarki untuk membagi dan mengatur ilmu pengetahuan dalam perpustakaan yang berdasarkan prinsip desimal. Di dalamnya dibagi menjadi kelompok-kelompok, yang masing-masing kelompok itu diberi angka dengan kelipatan seratus; misalnya untuk menunjukkan kelompok buku perihal agama ada pada 
urutan angka 200. Dalam praktiknya angka ini terdiri dari tiga digit, meskipun ekspresi teoritisnya bisa sangat panjang, dan angka-angka tersebut memungkinkan akan cepat diingat karena melalui pengulangan konstan dari pola standar.

Keberadaan Dewey Decimal System cukup membantu para kurator museum dan organolog untuk mengklasifikasikan instrumen musik dalam jumlah banyak. Termasuk pula untuk mengklasifikasikan instrumen kacapi indung dalam tembang Sunda cianjuran dengan menggunakan Dewey Decimal System pada klasifikasi Sachs dan Hornbostel.

\section{Kodifikasi Dewey Decimal System pada Instrumen Kacapi Indung}

Pada prinsipnya sistem kodifikasi ini berupa deretan angka-angka yang dapat bercabang. Contohnya pada digit pertama untuk angka 1 sebagai kode klasifikasi instrumen idiophone, angka 2 untuk kode klasifikasi instrumen membranophone, angka 3 untuk kode klasifikasi instrumen chordophone, angka 4 untuk kode klasifikasi instrumen aerophone, dan angka 5 untuk kode klasifikasi instrumen elektrophone.

Dewey Desimal System jika diaplikasikan pada instrumen kacapi indung secara detail, maka sistem kodifikasinya adalah 314.122. Kodifikasi 
tersebut tercatat juga di MIMO (Musical Instrument Museums Online) yakni sebagai berikut:

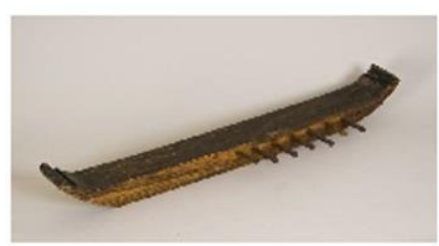

\begin{tabular}{ll} 
Collection & Collection Musical Instruments \\
\hline Inventory number & 0155 \\
\hline Object name & Kacapi \\
\hline Classification & $\begin{array}{l}\text { Musical instruments }>3 \text { Chordophones }>31 \\
\text { Simple chordophones or zithers }>314 \text { Board } \\
\text { zithers }>314.1 \text { True board zithers }>314.12 \text { True } \\
\text { board zithers with resonator }>314.122 \text { True } \\
\text { board zithers with resonator box (box zither) }\end{array}$ \\
\hline Title & Ketjapi, Kacapi, Kacapi indung
\end{tabular}

Gambar 24. Klasifikasi kacapi indung berdasarkan Dewey Decimal System.

(Sumber: MIMO, 2011).

Deretan angka tersebut jika diuraikan, yaitu kode angka 3 (digit pertama) menjelaskan bahwa kacapi indung termasuk pada klasifikasi chordophone. Angka 31, dengan ditambahnya angka 1 (digit kedua) menjelaskan kacapi indung termasuk pada subbagian chordophone yakni ziter. Angka 314, dengan ditambahnya angka 4 (digit ketiga) menjelaskan bahan yang digunakan yakni terbuat dari papan. Angka 314.1, dengan ditambahnya angka 1 (digit keempat) menunjukkan bidang dawai yang sejajar dengan dawai pengikatnya. Angka 314.12, dengan ditambahnya angka 2 (digit kelima) menunjukkan kacapi indung termasuk instrumen yang memiliki resonator. Angka 314.122, dengan ditambahnya angka 2 
(digit keenam) menunjukkan resonator pada kacapi indung berbentuk kotak (box). Terakhir penulis menambahkan satu digit di akhir (digit ketujuh) yaitu -5 untuk menunjukkan cara memainkan dari instrumen kacapi indung yang menggunakan jari-jari tangan secara langsung tanpa bantuan alat. ${ }^{21}$ Penggunaan minus pada digit (-5) sebagai sufiks yang digunakan terhadap pembagian chordophone, yang menunjukkan aspek cara memainkan instrumen. Dengan demikian kodifikasi instrumen musik kacapi indung yang menggunakan Dewey Decimal System Sachs dan Hornbostel adalah 314.122-5.

\section{Organografi dan Organogram Kacapi Indung}

Seiring dengan berkembangnya ilmu pengetahuan, terkadang ada sisi positif dan negatif atau pro dan kontra terhadap suatu bidang ilmu tersebut, termasuk pada sistem pengklasifikasian Sachs dan Hornbostel. Seorang etnomusikolog, yakni Mantle Hood, membuat sebuah metode ekspansi untuk mengklasifikasikan instrumen musik yang didasarkan pada klasifikasi Sachs dan Hornbostel dengan cara metode organografi dan organogram.

${ }^{21}$ Revision of the Hornbostel-Sachs Classification of Musical Instrument by the MIMO (Musical Instrument Museums Online) Consortium, 2011: 12-15. 
Penerapan metode organografi dan organogram Hood bukan berupa deretan angka seperti yang dibuat oleh Sachs dan Hornbostel, akan tetapi dengan menjelaskan beberapa aspek kontekstual melalui sebuah simbol dan angka yang dapat menginterpretasikan aspek tersebut. Aspek-aspek yang dimaksud Hood dalam organogram dan organografi berupa deskripsi fisik, di antaranya: teknik permainan yang meliputi informasi mengenai hubungan antara musisi dengan instrumen musik; fungsi musik berhubungan dengan masalah bahan dan skala nada; dekorasi berhubungan yang kaitannya dengan masalah kebudayaan; dan sosiobudaya berhubungan dengan masalah nilai dan makna instrumen yang di dalamnya ada unsur ritual atau magis, dan status sosial tokoh atau musisi.

Mantle Hood mengajukan lima simbol dasar yang digunakan untuk menganalisis sebuah instrumen musik. Tujuan Hood dalam membuat model kajian ini adalah untuk menyederhanakan sebuah instrumen dari bentuk-bentuk sesungguhnya. Latar belakang pembuatan taksonomi simbolik organogram ini terinspirasi dari adanya notasi laban yang mengkaji secara detail untuk menggambarkan sebuah gerakan dalam dunia tari. 
Organogram hampir semacam ideogram yang dapat mengemas banyak informasi dalam bentuk visual yang tidak terlalu sulit untuk berasimilasi. Hasil akhirnya akan menjadi simbol gabungan, di mana akan memberikan informasi unik untuk alat musik. Berikut adalah simbol atau gambar yang dibuat oleh Mantle Hood sebagai taksonomi simbolik organogram.

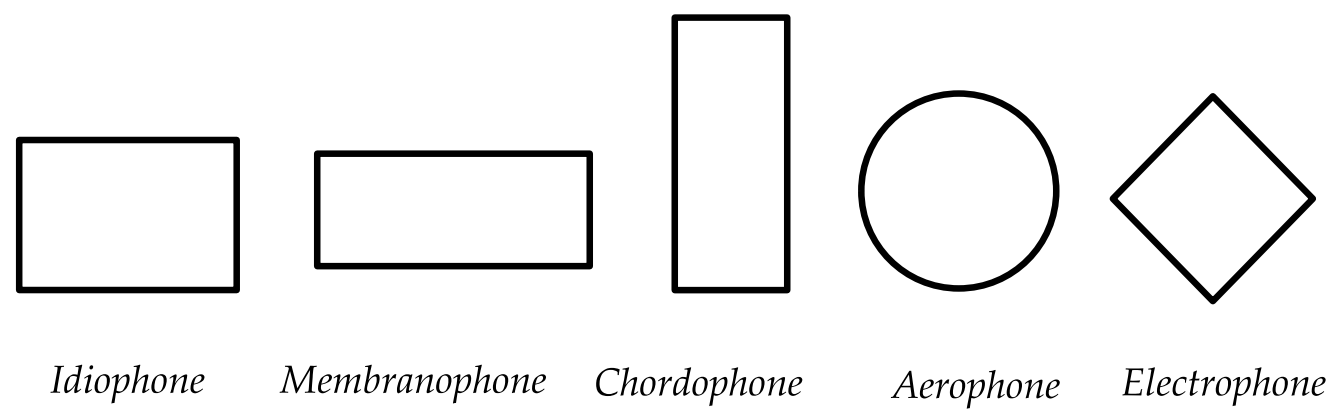

Gambar 25. Taksonomi simbolik organogram Mantle Hood.

(Sumber: Mantle Hood, 1982: 144).

Apabila instrumen kacapi indung dikaji menggunakan sebuah metode organografi dan organogram yang termasuk pada klasifikasi chordophone dengan aspek-aspek deskripsi fisik yang telah diuraikan di atas, akan tergambar seperti di bawah ini. 


\section{DAFTAR PUSTAKA}

Banoe, Pono. 2003. Kamus Musik. Yogyakarta: Kanisius

Budi, Dinda Satya Upaja. 2015. Angklung Dogdog Lojor Pada Masyarakat Kasepuhan Ciptagelar Kasatuan Adat Banten Kidul. Disertasi. Yogyakarta: Universitas Gajah Mada.

De vale, Sue Carole. 1990. Organizing Organology. Los Angeles: University of California.

Hendarto, Sri. 2011. Organologi dan Akustika I \& II. Bandung: CV.Lubuk Agung.

Herman. 2012. “Organologi dan Teknik Permainan Musik Tradisional Pakacaping Etnis Makassar Kabupaten Gowa Propinsi Sulawesi Selatan." Skripsi. Yogyakarta: Universitas Negeri Yogyakarta.

Hood, Mantle. 1982. The Ethnomusicologist. America: The Kent State University Press.

Kartomi, Margaret J. 1990. On Concept and Classification of Musical Instruments. Chicago: University of Chicago.

_ _ . 1985. Musical Instruments of Indonesia. Melbourne: Indonesian Arts Society.

Myers, Helen. 1992. Ethnomusicology An Introduction. New York: W. W. Norton \& Company, Inc.

Nettl, Bruno. 1930. The Study of Ethnomusicology, Thirty-One Issues and Concept. Urbana and Chicago: University Illinois Press.

Nugraha, Asep. 2007. "Pemain Kacapi Indung Seni Tembang Sunda Cianjuran: Kajian Peraihan Derajat Kompetensi." Laporan Penelitian Beasiswa Unggulan. Bandung: STSI Bandung.

- - - 2015. "Penelusuran Perkembangan Kacapi Sunda." Jurnal Parguna Vol. 2 No. 1. Bandung: Prodi Karawitan Fakultas Seni Pertunjukan ISBI Bandung, 130-43. 
Randel, Don Michael ed. 1969. The New Harvard Dictionary of Music. England: The Belknap Press of Harvard University Press.

Ruswandi, Tardi. 1995. Koko Koswara Pelopor Pembaharu Karawitan Sunda. Tesis. Yogyakarta: UGM. . 2017. Kawih Sunda Karya Mang Koko. Bandung: Sunan Ambu Press.

Sachs, Curt. 1940. The History of Musical Instruments. New York: W. W. Norton \&Company, Inc.

Soepandi, Atik dan Enoch Atmadibrata. 1983. Khazanah Kesenian Daerah Jawa Barat. Bandung: Pelita Masa.

Sukanda, Enip. 1996. Kacapi Sunda. Dirjen Kebudayaan DEPDIKNAS.

Wahyudin, Pepep Didin. 2007. Makna Simbolisme Kacapi Indung Dalam Tembang Sunda cianjuran Analisis Struktural Pada Penembang Terhadap Proses Pengarusutamaan Gender. Skripsi. Bandung: STSI.

Zanten, Wim van. 1989. Sundanese Music In The Cianjuran Style. USA: Foris Publications Holland.

Estrella, Espie. 2019. Classification of Musical Instruments: The SachsHornbostel System. Diunduh di https://www.thoughtco.com/classification-of-musical-instruments$\underline{2456710}$ tanggal 17 April 2019.

Hornbostel, E. M. \& Sachs, C. 1961. Classification of Musical Instruments: Translated from the Original German by Anthony Baines and Klaus P. Wachsmann. The Galpin Society Journal Vol 14, pp,3-29. Diunduh di http://www.jstor.org/stable/842168 tanggal 17 April 2019.

Kemdikbud. 2012. Kamus Besar Bahasa Indonesia. Diunduh di https://kbbi.web.id/kodifikasi tanggal 22 Februari 2019. 
Musical Instrument Museums Online Consortium. 2011. Revision of the Hornbostel-Sachs Classification of Musical Instruments by the MIMO Consortium.Diunduh di http://www.mimointernational.com/documents/Hornbostel\%20Sachs.pdf. Tanggal 17 April 2019.

Simbolon, Pardon. 2012. Mata Kuliah Akustika Organologi. Diunduh di http://pardonsimbolon.blogspot.com/2012/08/akustikorganologi.html tanggal 28 November 2018.

OCLC. 2019. Melvil Dewey Biografi. Diunduh di https://www.oclc.org/en/dewey/resources/biography.html tanggal 11 April 2019. 


\section{GLOSARIUM}

\section{A}

adiluhung

B

Baduy

C

carukan

cianjuran

chordophone

D

dalem

G

gelung

inang karya seni yang bernilai tinggi/agung.

kampung adat yang masih mempertahankan keaslian dari suku Sunda.

salah satu motif tabuhan kacapi dalam tembang Sunda cianjuran.

nama lain dari tembang Sunda cianjuran.

nama pengelompokkan alat-alat musik yang berdawai.

julukan masyarakat pribumi terhadap seseorang yang menjadi bupati.

lengkungan hiasan yang berbentul sanggul wanita pada kacapi indung, kacapi pantun, dan kacapi rincik.

penyangga dawai pada kacapi yang berbentuk piramid. 


\section{J}

juru pantun

K

kacapi indung

kacapi rincik

kacapi kawih

karawitanologi

kenitan

klasifikasi

kodifikasi

L

laras vokalis yang membawakan cerita pantun.

alat musik petik tradisional Jawa Barat, yang berbentuk seperti perahu dengan jumlah dawai 18 utas.

alat musik petik tradisional Jawa Barat, dengan jumlah dawai 15 utas.

alat musik petik tradisional Jawa Barat yang berbentuk tipis dan ringan dengan jumlah dawai 20 utas.

disiplin ilmu yang mempelajari perihal karawitan.

salah satu motif tabuhan kacapi dalam tembang Sunda cianjuran.

penyusunan dengan sistem pengelompokkan atau golongan.

pemberian nomor atau lambang pada perkiraan pos, jurnal, faktur, atau dokumen lain.

tangga nada atau scale. 
lisung alat untuk menumbuk padi.

M

mamaos

tembang Sunda langgam cianjuran yang berirama merdika, bebas ketukan.

Mang istilah bahasa Sunda yang artinya sebutan kepada orang yang sudah tua.

masieupan

salah satu motif tabuhan kacapi dalam tembang Sunda cianjuran.

O

organologi disiplin ilmu yang mempelajari organ atau bagian-bagian instrumen musik serta mencakup perihal cara memainkan hingga sosio-budaya.

organografi dan organogram metode yang mengklasifikasikan dengan berupa gabungan simbol-simbol.

P

pelog salah satu jenis tangga nada Sunda.

pureut alat untuk menyetemkan dawai pada kacapi atau rebab.

$\mathbf{R}$

rebab

instrumen Sunda yang dimainkan dengan cara digesek juga berdawai. Alat gesek ini berfungsi sebagai pembawa melodi. 
saléndro

suling

T

tumpang sari

V

visual

W

waditra

wangkis salah satu jenis tangga nada Sunda.

instrumen Sunda yang dimainkan dengan cara ditiup dengan berbahan bambu. Alat tiup ini berfungsi sebagai pembawa melodi.

salah satu bagian kacapi yang berfungsi sebagai penyangga dawai yang diikatkan pada baut. Posisi dari tumpang sari berderetan ke samping (menyerong) yang mengikuti panjang dari dawai.

dapat dilihat dengan indra penglihatan (mata) berdasarkan penglihatan.

alat-alat bunyi yang biasa dipergunakan sebagai alat musik tradisional.

salah satu bagian kacapi yang berfungsi sebagai penghantar getaran dawai. 


\section{LAMPIRAN - LAMPIRAN}

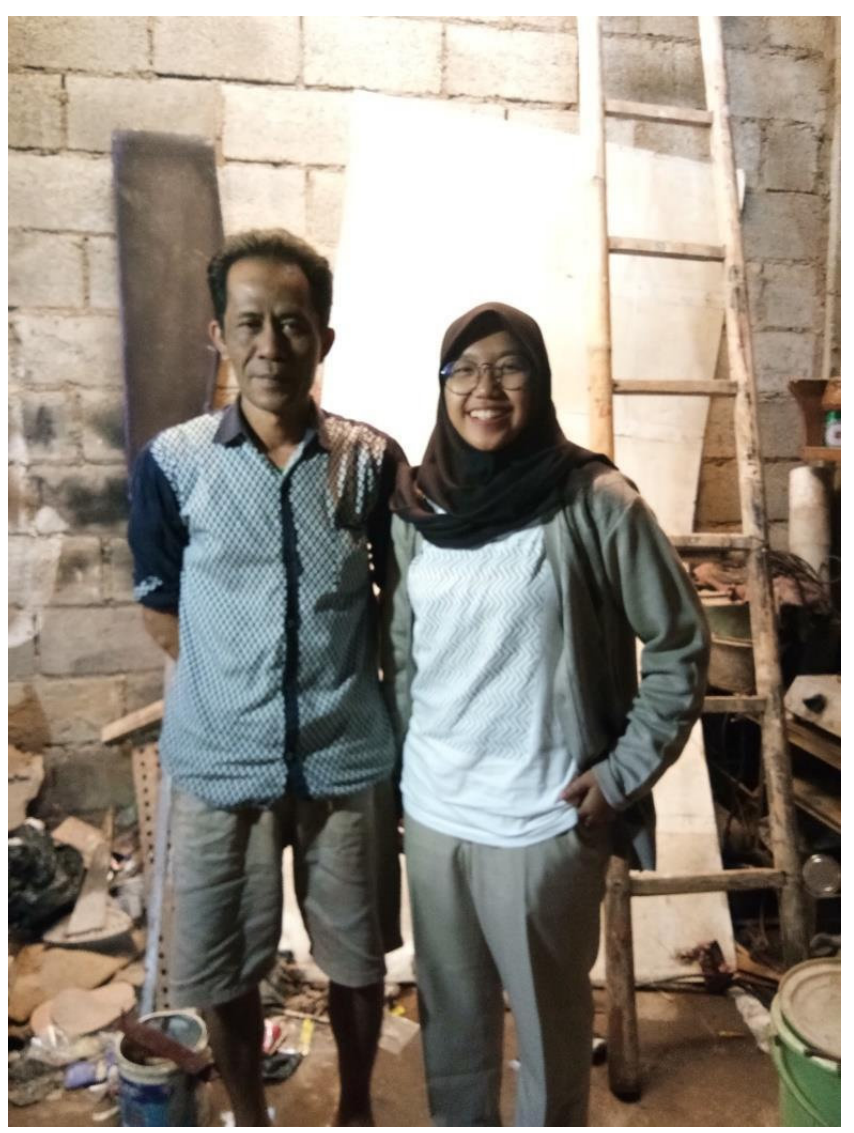

Dokumentasi penulis dengan narasumber.

(Sumber: Dok. Pribadi, 2019) 


\section{BIODATA NARASUMBER}

Nama

Tempat, Tanggal Lahir

Alamat

Profesi
: Desmon Suntara, S.S

: Bandung, 15 Juli 1972

: Jl. Sukaasih Atas - Sekepeer Rt 01 Rw 05, Kel.

Sindangjaya, Kec. Mandalajati Kota Bandung.

: Pengrajin kacapi 


\section{LOGBOOK}

\begin{tabular}{|c|c|c|c|}
\hline No & Tanggal & Kegiatan & Keterangan \\
\hline 1. & 18 Maret 2019 & $\begin{array}{l}\text { Studi pustaka pencarian } \\
\text { sumber literatur }\end{array}$ & $\begin{array}{l}\text { Perpustakaan ISBI } \\
\text { Bandung. }\end{array}$ \\
\hline 2. & $\begin{array}{l}24,29 \text { Maret } \\
\text { dan } 08 \text { April } \\
2019\end{array}$ & $\begin{array}{l}\text { Wawancara dan observasi } \\
\text { ke pengrajin kacapi. }\end{array}$ & $\begin{array}{l}\text { Salah satu pengrajin } \\
\text { kacapi khususnya } \\
\text { kacapi tembang Sunda } \\
\text { cianjuran yang telah } \\
\text { diakui } \\
\text { keterampilannya oleh } \\
\text { para pelaku seni. }\end{array}$ \\
\hline 3. & 09 April 2019 & Studi pustaka. & $\begin{array}{l}\text { Perpustakaan } \\
\text { DISPUSIPDA Jawa } \\
\text { Barat. }\end{array}$ \\
\hline 4. & 12 April 2019 & Penganalisis penelitian. & $\begin{array}{l}\text { Kampus ISBI } \\
\text { Bandung. }\end{array}$ \\
\hline 5. & 15 April 2019 & $\begin{array}{l}\text { Pengolahan data hasil } \\
\text { wawancara dan observasi. }\end{array}$ & \\
\hline 6. & 20 April 2019 & $\begin{array}{l}\text { Bimbingan materi } \\
\text { penelitian. }\end{array}$ & $\begin{array}{l}\text { Ruangan UPT TIK } \\
\text { ISBI Bandung. }\end{array}$ \\
\hline 7. & 09 Mei 2019 & $\begin{array}{l}\text { Bimbingan skripsi BAB III } \\
\text { dengan pembimbing I. }\end{array}$ & Via email. \\
\hline 8. & 10 Mei 2019 & $\begin{array}{l}\text { Bimbingan skripsi BAB I } \\
\text { dengan pembimbing II. }\end{array}$ & Via email. \\
\hline 9. & 13 Mei 2019 & $\begin{array}{l}\text { Bimbingan skripsi BAB III } \\
\text { dengan pembimbing I. }\end{array}$ & $\begin{array}{l}\text { Ruangan UPT TIK } \\
\text { ISBI Bandung. }\end{array}$ \\
\hline 10. & 23 Mei 2019 & $\begin{array}{l}\text { Bimbingan skripsi BAB III } \\
\text { dengan pembimbing II. }\end{array}$ & Via email. \\
\hline 11. & 25 Mei 2019 & $\begin{array}{l}\text { Bimbingan skripsi hasil } \\
\text { revisian BAB III dengan } \\
\text { pembimbing I. }\end{array}$ & Via email. \\
\hline 12. & 27 Mei 2019 & $\begin{array}{l}\text { Diskusi analisis dan teknik } \\
\text { penulisan dengan } \\
\text { pembimbing II. }\end{array}$ & $\begin{array}{l}\text { Kampus ISBI } \\
\text { Bandung. }\end{array}$ \\
\hline 13. & 29 Mei 2019 & $\begin{array}{l}\text { Bimbingan skripsi BAB III } \\
\text { dengan pembimbing I. }\end{array}$ & $\begin{array}{l}\text { Ruangan UPT TIK } \\
\text { ISBI Bandung. }\end{array}$ \\
\hline 14. & 11 Juni 2019 & Bimbingan skripsi BAB II. & \\
\hline 15. & 13 Juni 2019 & $\begin{array}{l}\text { Bimbingan skripsi BAB II } \\
\text { dengan pembimbing II }\end{array}$ & $\begin{array}{l}\text { Via email dan kampus } \\
\text { ISBI Bandung. }\end{array}$ \\
\hline
\end{tabular}




\begin{tabular}{|c|l|l|l|}
\hline & & $\begin{array}{l}\text { dan mengerjakan revisi } \\
\text { skripsi BAB II dari } \\
\text { pembimbing I. }\end{array}$ & \\
\hline 16. & 15 Juni 2019 & $\begin{array}{l}\text { Bimbingan skripsi } \\
\text { seluruh BAB dengan } \\
\text { pembimbing II. }\end{array}$ & Via email. \\
\hline 17. & 17 Juni 2019 & Pengumpulan skripsi. & $\begin{array}{l}\text { Kampus ISBI } \\
\text { Bandung. }\end{array}$ \\
\hline 18. & $\begin{array}{l}17-23 \text { Juni } \\
2019\end{array}$ & $\begin{array}{l}\text { Pembuatan poer point } \\
\text { presentasi siding skripsi. }\end{array}$ & \\
\hline 19. & $\begin{array}{l}24-25 \text { Juni } \\
2019\end{array}$ & $\begin{array}{l}\text { Pelaksanaan tugas akhir. } \\
\text { Sidang skripsi. }\end{array}$ & . \\
\hline
\end{tabular}




\section{BIODATA PENULIS}

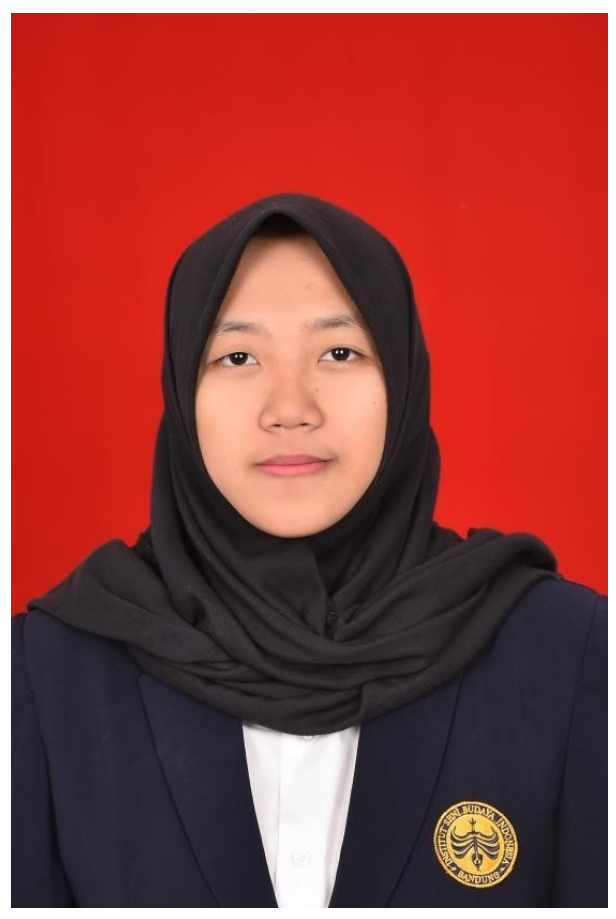

Nama

: Ani andriani

$\mathrm{Nim}$

: 15123049

Tempat, Tanggal Lahir $\quad$ : Bandung, 13 Februari 1998

Umur

: 21 Tahun

Agama

: Islam

Kebangsaan

: Indonesia

Alamat

: Kp. Sindangsari Rt 03 Rw 14, Ds.

Sangkanhurip, Kec. Katapang, Kab. Bandung

Selatan, Jawa Barat

Email

: ania10995@gmail.com 
Riwayat Pendidikan

- 2003 s/d 2009 SD Negeri 1 Cilampeni

- 2009 s/d 2012 SMP Negeri 1 Katapang

- 2012 s/d 2015 SMA Negeri 1 Soreang

- 2015 s/d 2019 Institut Seni Budaya Indonesia (ISBI) Bandung

Fakultas Seni Pertunjukan Jurusan Karawitan

Pengalaman berkesenian

- Mendukung resital karawitan tahun 2017

- Mengikuti festival musik kontemporer Sunda bersama grup kesenian SUNDA ETNIK tahun 2016 